\title{
Del poeta épico al maestro del arte de prudencia: Juan Rufo o la fábrica de una fama en vida y muerte
}

\author{
Mercedes Blanco \\ Sorbonne Université, equipo CLEA
}

Título: Del poeta épico al maestro del arte de prudencia: Juan Rufo o la fábrica de una fama en vida y muerte.

Resumen: Las ambiciones literarias y sociales de Juan Rufo, vástago dotado e inquieto de una familia cordobesa rica, plebeya y de estirpe conversa, fueron alentadas por su encuentro, al socaire de la guerra de las Alpujarras, con don Juan de Austria, quien lo tomó a su servicio. De ahí vino el impulso de un vasto y laborioso poema, La Austríada (1584): mostramos que el género épico elegido por Rufo, las soluciones estéticas que adoptó, su estrategia de legitimación, fueron condicionados por su perfil social en una coyuntura política, ideológica y literaria muy concreta. Para ello nos apoyamos en la segunda obra de Rufo, Las Seiscientas apotegmas y otras obras en verso (1596), que contiene confidencias personales y enunciados muy reveladores de la concepción del mundo del autor. Esta segunda obra no compensó la frustración y el "desengaño "motivados por el mediocre éxito de la primera; y sin embargo, estaba orientada hacia el futuro. Lo probamos mediante una investigación, todavía parcial, de su fama en la segunda mitad del XVII, momento en el surge, de mano de antólogos y comentaristas, un Rufo acorde con el gusto de esas décadas por una literatura moral basada en la agudeza, la brevedad y la singularidad.

Palabras clave: Juan Rufo, Austríada, Los Seiscientos apotegmas, épica, arte de la prudencia.

Fecha de recepción: 26/11/2018.

Fecha de aceptación: 09/12/2018.
Title: From the Epic Poet to the Master of Prudence: Juan Rufo or the Fabric of Fame in Life and Death.

Abstract: The literary and social ambitions of Juan Rufo, a gifted and restless scion of a wealthy, plebeian Cordovan family of Jewish descent, were encouraged by his encounter, because of political hazards, with Don Juan de Austria, who took him into his service. Hence came the impulse of a vast and laborious poem, La Austriada (1584): we claim that the choice of the epic genre and the aesthetic solutions adopted by Rufo, as well as his strategy of legitimation as an epic poet, were constrained by his social profile in a specific political, ideological and literary conjuncture. To support this thesis, we rely on his second work, Las Seisceintas Apotegmas (1596), which contains personal confidences and statements extremely revealing of the author's world view. This second work did not compensate the frustration and desengaño motivated by the mediocre success of the first; and yet, it was oriented towards the future. We demonstrate it through an investigation, still partial, of his fame in the second half of the seventeenth century, moment in which arises, thanks to anthologists and commentators, a Rufo according to the taste, typical of these decades, for a moral literature based on wit, brevity and singularity.

Key words: Juan Rufo, La Austriada, Las Seiscientas Apotegmas, epic poetry, art of prudence.

Date of Receipt: 26/11/2018.

Date of Approval: 9/12/2018. 
Los escritores que hasta ahora se ocuparon de nuestro biografiado, fundados no sabemos en qué erróneas suposiciones, hicieron de Rufo un prócer representante de Córdoba en las cortes de 1570 , de ilustrísima cuna y de heroica y noble vida. No; Juan Rufo ni hidalgo era siquiera; pertenecía al estado llano, y aunque toda su vida anduvo mal acomodado con su condición, no pudo nunca remontar sus vuelos, y, al fin y a la postre, se conformó con su estado de pobre tintorero.

Rafael Ramírez de Arellano, Juan Rufo, jurado de Córdoba, 1912

Juan Rufo, autor que gozó de notoriedad en su tiempo y fue bastante olvidado después, pese a la honrosa mención que de él hace Cervantes en el Quijote, tuvo la suerte de interesar a un erudito y escritor, amante de las glorias de Córdoba, Rafael Ramírez de Arellano, cuyas pesquisas le llevaron a reunir los materiales de una amena biografía publicada a principios del siglo XX. Entre los documentos que compiló no faltaban indicios de la estirpe judía de Rufo, pero él prefiere darlo, sin la menor prueba, por cristiano viejo, tal vez por temor a que los prejuicios antisemitas arraigados en la mayoría de sus lectores perjudicaran a la figura de su biografiado y a la recepción de su libro:

No daña a la condición de hombre de talento y de poeta brillante el modesto origen de este cordobés, ilustre por sus obras y considerándole con el criterio del siglo actual en que, si es agradable descender de afamados guerreros, no es denigrante engrandecerse por el propio trabajo. En los tiempos pasados también hombres excepcionales eran apreciados por su justo valor, y Rufo, como su paisano Antón de Montoro, y como Rodrigo Cota, Juan Alfonso de Baena y tantos otros de humilde cuna, y aun mala cuna, pues los citados eran judíos conversos, supieron elevarse y merecieron la consideración de reyes, príncipes y magnates, a la que se hicieron acreedores por sus felices disposiciones poéticas. Rufo, si no era noble, era de familia honrada, cristiana vieja y que gozaba en su patria de alguna consideración y respeto ${ }^{1}$.

1 Rafael Ramírez de Arellano, Juan Rufo jurado de Córdoba. Estudio biográfico y crítico. 
Ramírez de Arellano no vacila en parafrasear los materiales que maneja, dándoles un aire de novela, lo que por aquel entonces se consideraba modo normal de proceder. En el índice de 253 documentos incluido al final del volumen figuran varias decenas de apotegmas de Juan Rufo y alguno de su hijo Luis, con los mismos derechos que las partidas de nacimiento y defunción, las escrituras de compra y venta, los contratos, los poderes, obligaciones, arrendamientos y fianzas. Aunque ilegítimo en buen método histórico, este procedimiento tiene la virtud de poner de relieve la índole autobiográfica de la curiosa colección de anécdotas y dichos ingeniosos que publicó Juan Rufo en 1596, ocultada por la forma clásica y renacentista de la floresta o silva, esto es, colección desordenada de textos breves. Quien quisiera escribir una confesada novela sobre este interesante personaje tendría ahí más material del necesario, aunque explotarlo inteligentemente no sea fácil.

De linaje plebeyo y, como ahora sabemos, converso ${ }^{2}$, Juan Rufo, nacido hacia $1547^{3}$, fue hijo del "tintorero" cordobés Luis Rofos, un mercader de paños y de maderas de construcción, propietario de una buena casa en la ciudad y de una heredad en el campo, a quien los estudiosos del poeta califican de "humilde", pero que era, en verdad, hombre rico y muy avisado. De un interesante codicilo del testamento de Luis Rofos y de las actas de reuniones del cabildo de Córdoba, se desprende que, en torno a sus veinte años, Juan Rufo robó repetidas veces a su progenitor para gastar en sus diversiones y vicios; que en varias ocasiones su padre se vio forzado, para librarlo de la cárcel, a pagar la dote de muchachas a quienes había seducido; que, cuando se le confió el cargo de mayordomo del pósito, defraudó a la ciudad de parte del trigo cuya administración se le había confiado y tuvo que sostener por ello un largo pleito. Todo ello no consiguió privarle de la simpatía de su biógrafo cordobés; sí, en cambio,

Premiado con accésit por la Real Academia Española e impresa a sus expensas, Madrid, Hijos de Reus, 1912, p. 8.

2 Véase el artículo de Enrique Soria Mesa en este monográfico.

3 No hay documentos que lo prueben directamente: el ańo de nacimiento es conjetura verosímil de Ramírez de Arellano basada en la edad que se atribuye Rufo en la orla de su retrato que adorna la edición de La Austríada y en la fecha, 1544, del casamiento de sus padres, de quien era el hijo segundo. 
de la de Agustín González de Amezúa. En la amplia introducción que este crítico puso al frente de su edición de los Apotegmas (1923), incluye varias páginas de fulminante severidad, basadas en los documentos hallados por Ramírez de Arellano, a quien encuentra demasiado indulgente:

Nacido en 1547, el mismo año que Cervantes, de humilde cuna, en la ciudad de Córdoba, transcurre su juventud en una no interrumpida serie de locuras, insolencias y picardías, que a su padre, honrado tintorero con tienda abierta en aquella ciudad, llenan de preocupaciones y disgustos [...]. Con los años fue creciendo en nuestro escritor la afición a la vida suelta, ociosa y desgarrada, y como los pecados capitales rara vez huelgan de la soledad, sino que gustan de verse en compañía unos con otros, el Amor llevóle de la mano al juego y el juego le echó en brazos de Baco, haciendo de Rufo, a la postre, el acabado tipo del hidalgo sin oficio ni blanca [...]. Por mucho que se revuelvan los numerosos documentos descubiertos por su biógrafo (por cariño de tal, tolerante muchas veces con sus flaquezas y caídas), difícilmente se hallarán otras escuelas o estudios [que las tabernas y mancebías] donde pudiera cursar Rufo 4 .

González de Amezúa, animado por la indignación esperable en un buen burgués de su siglo y condición, sale de su papel de historiador para erigirse en censor y en predicador. Deforma así la visión de un personaje complejo, reduciéndolo a una figura "apicarada, chocarrera y maleante": de hecho, lo calumnia sin escrúpulos, porque ningún testimonio indica que nuestro personaje fuera un borracho empedernido, como él supone, convencido de que todos los vicios se dan de la mano y que es imposible incurrir en uno sin tenerlos todos. Si esta visión caricaturesca de Rufo mereciera absoluto crédito, no se entendería que fuese capaz de escribir La Austríada, obra que exigió una larga aplicación, ni otros hechos igualmente incontrovertibles.

Rufo ocupó el cargo municipal de jurado apenas salido de la adolescencia, lo cedió teniendo veintidós o veintitrés años y en las dos décadas siguientes profesó como cortesano, reforzando esta dedicación con algún

4 Juan Rufo, Las seiscientas apotegmas y otras obras en verso, Madrid, Sociedad de Bibliófilos Españoles, 1923, pp. XI-XIII. 
episodio militar 5 . Esta actividad inseparablemente cortesana y literaria, que no se daba por descontada para un hombre de su linaje ${ }^{6}$, se hizo posible por el favor de don Juan de Austria, que solo puede explicarse por el encanto y la gracia del favorecido. El joven cordobés pudo entrar en contacto con el príncipe cuando este, al mando de las tropas del rey contra los moriscos sublevados, trató con las autoridades municipales de Córdoba, la ciudad en territorio pacífico más cercana a la zona de combate, para que le proveyeran de hombres, víveres, armas, caballos y bestias de carga. Según su propio testimonio, ya terminada la campaña, viajó a Madrid para felicitarlo en nombre de la ciudad por su victoria, justo después de renunciar al cargo de jurado en favor de su padre. Lo seguro es que el "cesarino Aquiles", como lo llama Rufo en La Austríada, lo tomó a su servicio a finales de 1570 o inicios de 1571, estimando, al parecer, que protegía a un poeta capaz de celebrar la acción bélica ya terminada y la más gloriosa que se preparaba contra los turcos. No sabremos nunca por qué se decidió por Rufo; no por su erudición, que ciertamente no era sobresaliente, y menos por la distinción de su obra poética, que por entonces debía de limitarse a algún soneto, a alguna copla de repente y a lo sumo a algún romance, como el de los comendadores de Córdoba: una composición ciertamente excepcional por su extensión y por las constantes agudezas que tanto gustaron a Gracián, pero cuya fecha ignoramos y

5 La documentación disponible sobre Rufo apenas parece haber aumentado desde el libro de Ramírez de Arellano. No hace mucho se le han incorporado, sin embargo, dos cartas del escritor al cardenal Ascanio Colonna, publicadas por Patricia Marín Cepeda, "Entre pliegos anda el juego: Juan Rufo y las cortes literarias en el tiempo de la Austríada”, Calíope, XXII, 1, (2017), pp. 165-188. El artículo nos permite asomarnos a las andanzas por Madrid y Alcalá de Juan Rufo, en el momento en que se ocupaba de la edición de La Austríada y trataba de hacerse un lugar en el ambiente cortesano entre varios patrones aristocráticos.

6 La vocación de Rufo no era ciertamente la de las armas. Su hermano menor, Tomás Gutiérrez, travieso y dilapidador de la fortuna del padre, lo mismo que él, participó, según declara Luis Rofos en el codicilo de su testamento, en la guerra de Granada, al mando de una compañía de aventureros para la que el tintorero costeó armamento y vestuario. Llegó al grado de capitán, y abandonando a su mujer en casa del padre, corrió mundo por Italia e Indias. En cambio, el poeta mandó a un sustituto en su lugar cuando la necesidad de alistar gente se hacía más urgente. Véase Rafael Ramírez de Arellano, op. cit., pp. 18-19. 
que bien podría ser más tardía que el poema épico ${ }^{7}$. El hijo del tintorero debía de tener fama de disipado y manirroto, aunque también de entendido y discreto y, ante todo, de ocurrente e ingenioso en grado superlativo. Lo indudable es que fue del gusto de don Juan, que lo introdujo en su casa, en su corte, si se puede hablar en estos términos, lo que cambió su destino. Su perfil social y su personalidad daban pie a la sospecha de que el príncipe lo tuviera a su lado más como hombre de placer, o criado gracioso, que como docto consejero. Pero lo cierto es que pudo encarnar, a ojos de otros, mejor intencionados, el ideal renacentista del vir doctus et facetus, dos caras que corresponden a las dos obras impresas que nos han quedado de él: la muy seria y ardua Austríada, que salió en 1584 de las prensas madrileñas ${ }^{8}$, y una obrita de formato pequeño y lectura leve, Las

7 Ramírez de Arellano cree que este enorme romance de 1240 octosílabos fue escrito por Rufo en su primera juventud e incluso conjetura que, por haber demostrado con él que su musa estaba a la altura de asuntos graves y trágicos, se decidió su autor a lanzarse a la ardua empresa de La Austríada (p. 32). No hay prueba alguna de que así fuera. Los dos testimonios conocidos del "Romance de los comendadores" aparecen en dos impresos toledanos del año 1596 (quince años después de terminado el poema épico), uno en la princeps de los Apotegmas y otras obras en verso de Rufo y otro en Luis de Medina, Flores del Parnaso (Toledo, 1596). Volumen 10 de Las fuentes del Romancero general, ed facsímil de A. Rodriguez Moñino, Madrid, Real Academia Española, 1957, donde figura, como es costumbre en este tipo de libros, sin nombre de autor. Véase Pedro Ruiz Pérez, "Paradigmas genéricos en un romance de Rufo. 'Los comendadores' y la épica culta”, Rilce, 7, (1991), pp. 109-131. Parece lo más probable que este texto erizado de agudezas se compusiera en plena moda del romancero nuevo, o sea, en torno a 1590. Las dos versiones del romance son muy distintas, y la de Flores del Parnaso se reproduce en el Romancero general, añadido y enmendado por Pedro Flores, Madrid, Juan de la Cuesta, 1614, ff. 263v-269r. No sabemos que haya una edición crítica y comentada de este romance que inspiró a Lope de Vega su comedia Los comendadores de Córdoba, lo que es lástima. Las siete citas de fragmentos de este texto que incluye Gracián en Agudeza y arte de ingenio, presentan variantes con respecto a ambos testimonios.

8 La Austríada de Juan Rufo, jurado de la ciudad de Córdoba, dirigida a la S.C.R.M. de la Emperatriz de Romanos, reina de Bohemia y Hungría, etc. Madrid, Alonso Gómez, 1584. Fue reimpresa en Toledo en 1585 y en Alcalá en 1586. El poema fue incluido en un tomo de la BAE, Poemas épicos, II, ed. Cayetano Rosell, Madrid, Atlas, Biblioteca de Autores Espańoles 29, 1854, pp. 1-136. Cuenta con una buena edición reciente: Juan Rufo, La Austríada, ed. Ester Cicchetti, Pavía, Ibis, 2011. Citaremos por la prínceps, modernizando la grafía y la puntuación. 
seiscientas apotegmas y otras obras en verso ${ }^{9}$, publicada en Toledo doce años más tarde. Pretendemos aquí esbozar una interpretación de Rufo como la suma de esas dos obras, o como el Jano capaz de concebir dos libros tan diferentes. De este vir doctus et facetus, docto y donoso, culto pero agraciado y entretenido, de estirpe ciceroniana y pontaniana ${ }^{10}$, hay ejemplos en otros andaluces de su tiempo, como Cristóbal Mosquera de Figueroa, letrado, magistrado y erudito, autor de dos paradojas jocosas en loor de las narices grandes y de la sífilis ${ }^{11}$. El humor de Rufo, con un bagaje de cultura escolar menor que el de Mosquera, era más cortesano, más suelto, menos arraigado en la tradición humanista, razón por la cual resultó finalmente más interesante para el público de finales del XVII. Nos ocupamos en primer lugar del modo en que él mismo construyó su figura de escritor, sin llegar a consolidarla; luego, de la revancha relativa que tuvo su mediocre éxito en una discreta fama póstuma. Estos dos momentos de la recepción corresponden a las dos caras de su obra que hemos señalado.

9 Las seiscientas apotegmas de Juan Rufo. Y otras obras en verso. Dirigidas al Príncipe Nuestro Señor, Toledo, Pedro Rodríguez, 1596. Es la única edición antigua que ha llegado hasta nosotros. En 1923, la Sociedad de Bibliófilos Españoles publicó la obra a cuidado de Agustín González de Amezúa. Cuenta con otra edición bastante difundida: Juan Rufo, Las seiscientas apotegmas y otras obras en verso, ed. Alberto Blecua, Madrid, Espasa-Calpe, 1972. El mismo Alberto Blecua la editó de nuevo en Juan Rufo, Apotegmas, Sevilla, Clásicos andaluces, Fundación José Manuel Lara, 2006, edición que sentimos no haber podido consultar. Blecua numera los apotegmas, que no lo estaban en la prínceps. Utilizamos su numeración pero citamos por la edición antigua, modernizando grafía y puntuación.

10 El ideal, plasmado en muchos humanistas célebres, desde Poggio Bracciolini hasta Erasmo y Tomás Moro, fue teorizado con profundidad y elegancia por este poeta e intelectual, orgullo de la Nápoles aragonesa: Giovanni Gioviano Pontano, De Sermone. De la Conversation, ed. Françoise Bistagne, Paris, Champion, 2008.

11 Valentín Núnez Rivera, "Mosquera de Figueroa, vir doctus et facetus" en Cristóbal Mosquera de Figueroa, Paradoja en loor de la nariz muy grande. Paradoja en loor de las bubas, ed. Valentín Núñez Rivera, Salamanca, Universidad de Salamanca, 2010, pp. 113-117. Las caras januales de Mosquera de Figueroa coinciden punto por punto con las de Rufo; no sólo porque redactara los enkómia parádoxon de las narizotas y las bubas, sino también porque es el autor de un ambicioso prosímetro de signo panegírico titulado Elogio al retrato de don Álvaro de Bazán. Acaba de publicarse un estudio sobre esa pieza poético-oratoria: José Ignacio Díez, "Un prosímetro panegírico de Cristóbal Mosquera de Figueroa: el Elogio al retrato de don Álvaro de Bazán”, Criticón, 132 (2018), pp. 71-84. Agradezco la redacción de esta nota a Jesús Ponce Cárdenas. 


\section{Estrategias De LEgitimación DEL POETA ÉPICO}

Ningún documento permite asegurar que Rufo sirviera a don Juan de Austria con un cargo determinado y un estipendio fijo, y parece de todos modos poco probable, dadas su juventud y nula acreditación como erudito, que se le empleara oficialmente como cronista ${ }^{12}$. Probablemente mentía o exageraba en la "carta en tercetos" a una dama, donde se alaba de haber tenido "gajes de escritor" y "asiento honroso", por un cargo tan esencial e "ilustre" como el "cuidado" de la fama del príncipe:

Ya sabes que este príncipe famoso me dio el cuidado ilustre de su fama, con gajes de escritor, y asiento honroso ${ }^{13}$.

Pero, de modo informal, sí parece que don Juan aceptó los servicios del joven cordobés en calidad de poeta dedicado a escribir sus hazańas; y con ese cometido Rufo acompañó al príncipe a Italia y se embarcó con él en la flota de la Liga. O al menos así se cree generalmente, aunque el interesado en ningún momento cuenta la expedición y la batalla como quien hubiera visto con sus propios ojos lo sucedido y menos como quien hubiera participado activamente en el combate. En cambio, no calla que fue con la ayuda de "relaciones" y testimonios escritos, que el secretario de su patrón se encargó de facilitarle, como se lanzó a escribir lo que él llama una "historia" o "verdadera historia" en octava rima: un poema en veinticuatro cantos, según el patrón homérico de la Ilíada y de la Odisea, pero

12 Véase la respuesta del director del Archivo de Simancas a la consulta de Rafael Ramírez de Arellano, op. cit., p. 199: “...se ha procedido a la busca de los antecedentes del cronista de don Juan de Austria, Juan Rufo o Juan Gutiérrez Rufo. Reconocidos los libros de Casa Real, los legajos de la Recámara de don Juan de Austria y las Contadurías generales, y a pesar de que en estas se hallan las nóminas de varios cronistas, en ninguna de dichas series resulta el nombre de tal cronista. En las quitaciones de Casa Real ni en las de Corte tampoco aparece".

13 "Aquel que te ofrecí, Filena mía" (Carta en tercetos, a una dama), Los seiscientos apotegmas, fol. 25r. En esta interesante muestra del género epistolar, Rufo saluda a su amante a la que ha dejado para trasladarse a Italia en compañía del famoso hijo de Carlos $\mathrm{V}$ y le cuenta su viaje y su nueva condición. 
dividido (como la Eneida) en dos partes diferenciadas, aunque desiguales. En la primera, el poeta narra la guerra de las Alpujarras contra los moriscos rebeldes (siguiendo principalmente la Guerra de Granada a Diego Hurtado de Mendoza ); en la segunda, la expedición de la Santa Liga que desembocó en la resonante victoria de Lepanto contra la armada turca. La figura de don Juan es el vínculo entre ambos argumentos, que abarcan sucesos ocurridos desde el otoño de 1568, con los inicios del alzamiento de los moriscos granadinos, al 7 de octubre de 1571, fecha de la famosa batalla; sucesos, pues, recientes en el momento de la escritura. La ciudad de Córdoba y el reino de Castilla dan fe, en sendos documentos firmados por sus representantes, de que quien escribió el poema estaba al servicio del héroe y de su fama. Estos textos, una carta y un memorial, que fueron insertos en los preliminares de La Austríada, confieren a Rufo y a su poema considerable autoridad: un poco como si Aquiles hubiera encargado a Homero escribir la Ilíada y varios magistrados lo hubieran certificado en inscripciones oficiales. El interesado se encarga de corroborarlo en la dedicatoria, fechada el 20 de marzo de 1580, a la emperatriz viuda, hermana de don Juan, María de Austria, que acababa de llegar a Madrid:

Su Alteza me mandó ocupar en escribir su vida que, con ser breve, dio larga materia en que volasen muchas plumas mejores que la mía, y si hizo elección de ella, siendo tan falta de lo que a otros sobra, debió ser porque sus hechos esclarecidos tenían poca necesidad del ornamento y primor de los elocuentes y graves escritores.

Entre esta dedicatoria y el prólogo se inserta un grabado con el retrato en busto del autor, rodeado de una orla con inscripción latina: Ioannis Rufi cordubensis efigies aetate sua XXXVII (Fig. 1). Lleva un atuendo muy parecido al que luce Alejandro Farnesio, personaje del poema y sobrino de Juan de Austria, en un lienzo de Sofonisba Anguissola que lo representa hacia 1561, cuando vivía, todavía adolescente, en la corte de Madrid (Fig. 2): jubón con cuchilladas, cuera o coleto con cuello alto y cerrado por una apretada fila de botones decorativos, por el que asoma una lechuguilla, ferreruelo, o capa corta, abierta con una estudiada asimetría, y con amplio cuello alzado que enmarca la figura y la realza. Claro que el ferreruelo del hijo del tintorero no debía de ser de brocado forrado de armiños, ni debían de ser perlas los botones del coleto, ni se completaban 
estos atavíos con una gorra bordada de perlas y coronada de plumas de avestruz, pero la comparación del retrato del poeta con el del opulento príncipe muestra que el primero quiso presentarse al mundo con galas aristocráticas. El grabador ha dado al coleto abotonado hasta la barbilla, tal vez una cuera de piel, un brillo metálico de armadura, asociando así las galas cortesanas con el aire militar.

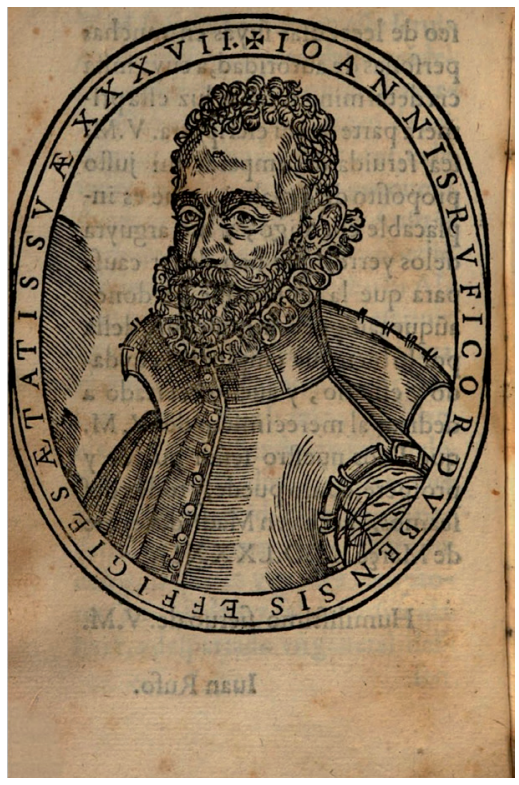

Fig 1: Retrato de Juan Rufo (La Austriada, 1584).

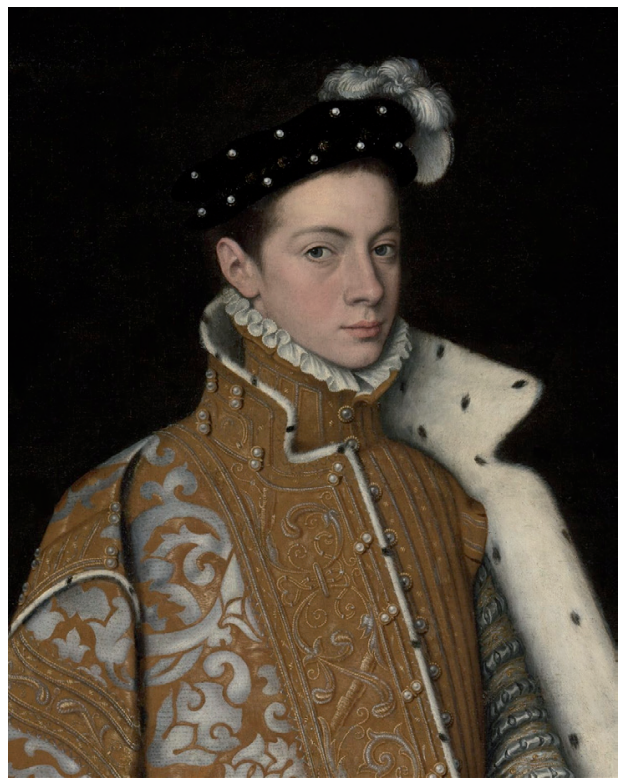

Fig. 2: Sofonisba Anguissola, Retrato de Alejandro Farnesio, Dublín, National Museum of Ireland.

Durante su período de actividad literaria, nuestro autor cambió su nombre de Juan Gutiérrez, apellido que llevaban sus tíos paternos y sus hermanos, por el de Juan Rufo, latinizado en la orla del retrato como Ioannis Rufus. Según Rafael Ramírez de Arellano, el documento más temprano que deja constancia de este nombre data del 6 de diciembre de 1578, cuando su portador contaba ya unos treinta ańos. Se trata de la ya aludida "Carta de la ciudad de Córdoba a la Majestad del rey don Filipe, Nuestro Señor", impresa en los preliminares de La Austríada. Dos meses después de la muerte de Juan de Austria, la ciudad recomienda al soberano una de las cosas que ha producido útiles en el servicio 
de Su Majestad, o sea "el ingenio y virtud del jurado Juan Rufo"; "un hijo de Córdoba, capaz de ser amparado y favorecido" porque "ha siete años que escribe una historia que parece que durará muchos siglos”, y "por ser hechura de Su Alteza”, esto es, protegido del difunto príncipe. La ciudad, por la pluma de tres de sus regidores, el licenciado Gómez del Castillo, don Gómez Fernández de Córdoba y Pedro de Hoces, pide que se le "haga merced para que su pretensión vaya adelante", sin decir de qué pretensión se trata, aunque se adivina que lo que solicita "el jurado Juan Rufo" es ayuda económica y aprobación real para concluir su labor literaria que se ha quedado sin arrimo después de fallecer su protector el 1 de octubre de 1578, es decir, dos meses antes de la fecha de la carta. Sin embargo, según Ramírez de Arellano, hasta el 30 de marzo de 1579 el escritor sigue firmando Juan Gutiérrez; del 1 de abril data un documento donde aparece el nuevo nombre como una especie de cognomen, bajo la forma Gutiérrez Rufo. Después de volver algún tiempo al apellido primitivo, empieza a firmar Juan Rufo Gutiérrez ${ }^{14}$. A partir de 1604 , cuando se hace cargo de la tintorería paterna, ya abandonados sus tratos cortesanos y su actividad literaria, desaparece Rufo de los documentos y reaparece Juan Gutiérrez a secas. Es, pues, por las fechas en las que se hace pública su figura de autor de una "historia" de Juan de Austria "en octava rima", cuando aflora y luego queda fijado "Rufo", nombre literario de una "hechura del príncipe", del fiel criado encargado de su gloria póstuma. El nombre insinúa, por su parecido con el Rofos paterno, que no es un mero seudónimo literario sino un patronímico de estirpe romana restablecido en su prístina pureza. Observa Ramírez de Arellano que, poco antes de que se forjara este nombre, en Las antigüedades de las ciudades de España del humanista cordobés Ambrosio de Morales, obra impresa en Alcalá en 1575 (él escribe 1577), se publicaron dos inscripciones en las que aparece el cognomen Rufus: una de ellas es la basa, hallada en Córdoba, de una estatua de Quinto Herennio Rufo, "hombre muy principal”, según Morales (Fig. 3).

14 Rafael Ramírez de Arellano, op. cit., p. 44. 

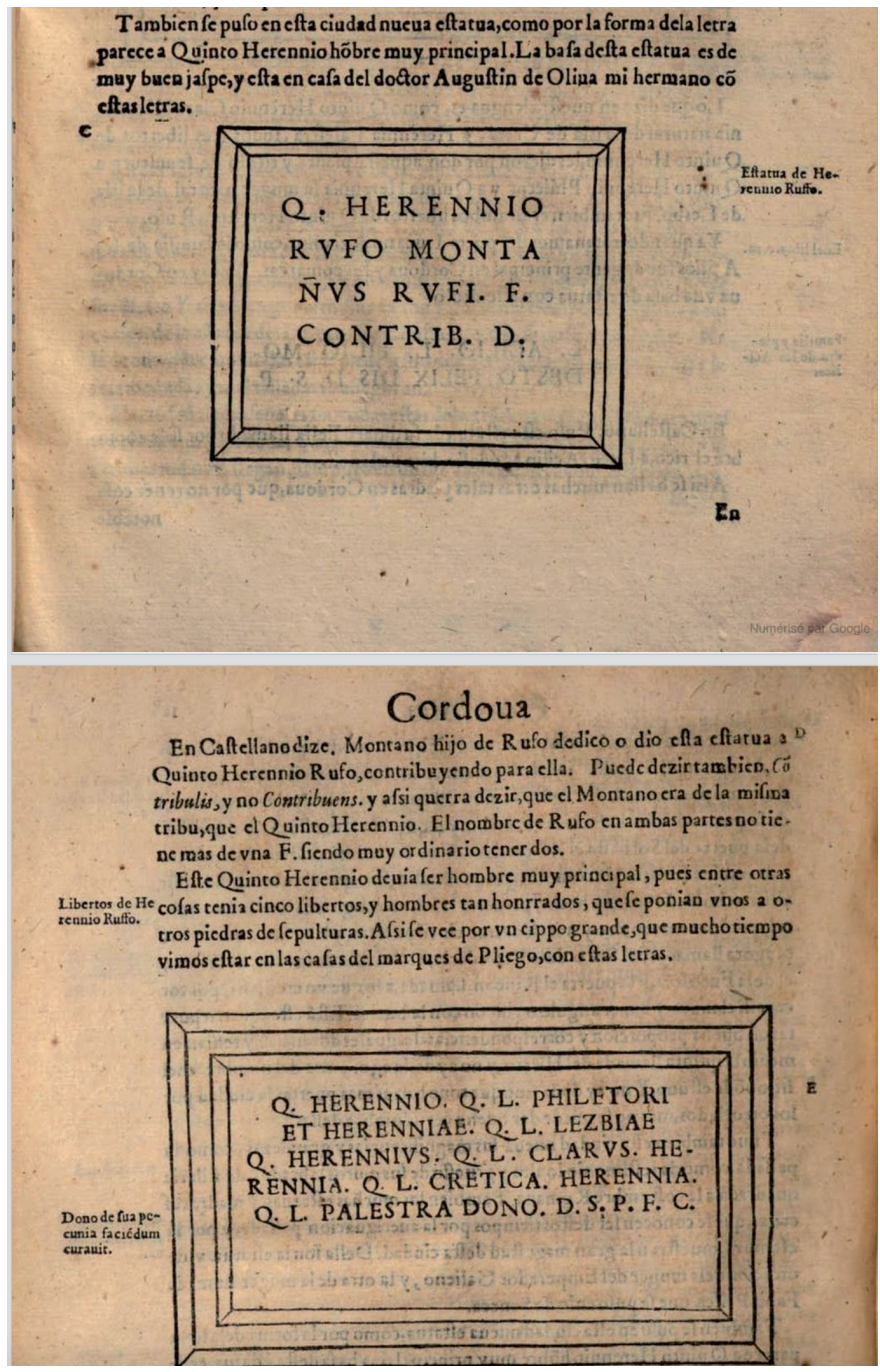

Fig. 3: Inscripción cordobesa en honor de Quinto Herennio Rufo, según Ambrosio de Morales

No sin ironía, escribe el biógrafo:

nuestro Rufo, al enterarse de que en tiempo de los romanos hubo en Córdoba un Rufo a quien se levantó una estatua, debió de creerse descendiente de aquél y dedujo del Rofos de su padre el Rufo con que en adelante firmó, haciendo más verosímil esta hipótesis, que 
algunos calificarán de demasiado sutil y demasiado poco fundada: el que antes de la publicación de este libro ni Juan ni su hermano Pedro usaron tal apellido. Rufo vino a ser de un abolengo mucho más antiguo, y por lo tanto, más ilustre que aquéllos sus paisanos que se apellidaban a sí propios, en escrituras y otros documentos, el muy magnífico señor Rodrigo Méndez de Sotomayor, por ejemplo ${ }^{15}$.

Nuestro autor nace, o renace, de una operación ingeniosa de auto-designación, como don Quijote de las cavilaciones del ingenioso hidalgo Alonso Quijano, dejando de ser Juan Gutiérrez, para ser el muy principal Juan Rufo, con vistas a publicar dignamente su poema épico, La Austríada. Tardará todavía otros cinco años en ser impresa la tal historia destinada, en la esperanza de sus compatriotas, a llegar a la posteridad.

La estirpe romana (insinuada tan solo, porque Rufo era demasiado sagaz y tenía demasiado sentido del ridículo para afirmarla taxativamente), fundada en una agudeza nominal y respaldada no menos que por la "memoria de las piedras"16, era la dignificación que necesitaba el novel autor, hijo de un hábil negociante de ascendencia hebrea, para tomar a su cargo la fama inmortal de un hijo de Carlos V, escribiendo un poema de metro, asunto y tonalidad heroicos. También le ayudó el cargo municipal de jurado de Córdoba, cuyos detentores se llamaban a sí mismos caballeros y señores, como se ve en los documentos editados por Ramírez de Arellano. La provisión real para este cargo fue adquirida por Luis Rofos o Gutiérrez, a quien el cabildo rechazó el ingreso entre sus miembros, al parecer por temor a que su condición de tintorero y propietario de tienda, o más bien su mancha demasiado notoria — de la que nunca se habla expresamente-, tiñesen también a sus colegas. Sin darse por vencido, Rofos renunció al cargo a favor de su hijo, nuestro Juan Rufo, que tomó posesión de él el 10 de julio de 1568, con poco más de veinte ańos, y lo ocupó durante algún tiempo, aunque con muchos descuidos e irregularidades, para acabar cediéndolo de nuevo al padre. Gracias al título de “jurado", que también sería, como veremos, importante en su memoria

15 Rafael Ramírez de Arellano, op. cit., p. 145.

16 Tomamos la expresión del título del libro de Miguel Morán Turina, La memoria de las piedras. Anticuarios, arqueólogos y coleccionistas de antigüedades en la España de los Austrias, Madrid, CEEH, 2010. 
póstuma, su nombre no está desamparado de título en los preliminares de La Austríada y de Las seiscientas apotegmas.

El título de jurado de la ciudad de Córdoba no equivale desde luego a los de caballero de Santiago y gentilhombre de la cámara del Emperador que ostenta don Alonso de Ercilla en ciertas portadas de la Araucana (Fig. 4), el antecedente más cercano y famoso de su poema, y con el que Rufo debió de querer competir.

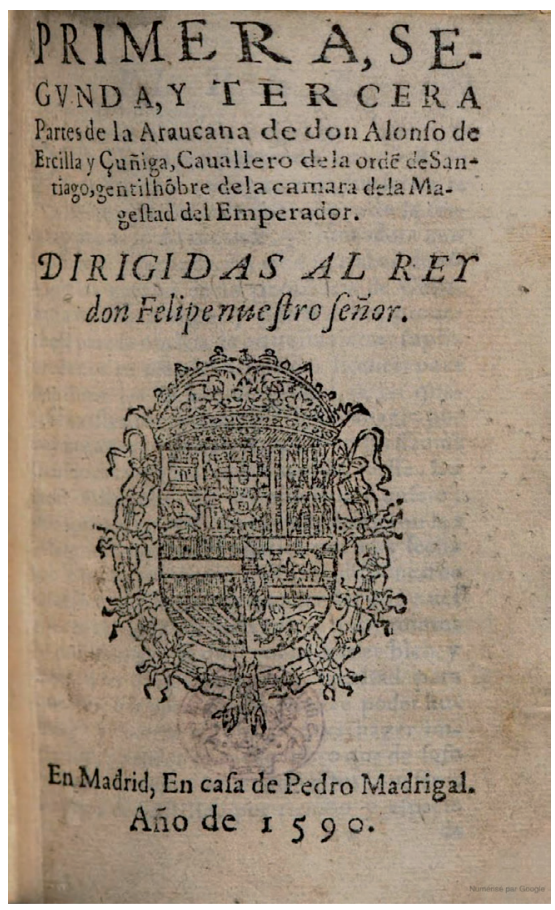

Fig. 4 : Portada de la Araucana, Madrid, Pedro Madrigal, 1590.

Sin embargo, al estar en posesión de esta dignidad, Rufo, hijo de sus obras $\mathrm{y}$ de las mercedes del príncipe difunto, pudo beneficiarse, al faltarle un patrón muerto en plena juventud, del respaldo de una ilustre ciudad con representación en cortes y glorioso pasado romano que lo reconocía como hijo bien amado suyo. Ser cordobés y ser jurado, y llamarse, por propia decisión, Rufo: he aquí lo que en el caso de nuestro autor hace las veces de nobleza, y dota del rango mínimo necesario para aspirar a escribir una 
historia inmortal, en un estilo "que durará muchos siglos", más perenne que el bronce, en fórmula horaciana. Estas dignidades anticuaria, municipal y ciudadana vienen a paliar, aunque solo de modo precario, la pérdida del principesco protector.

Las bases sociales de la fortuna de Rufo y el modo en que jugó las cartas que estas le procuraban, volviéndose un ingenio cortesano y un poeta, podrían ser comparados a los de Gutierre de Cetina, otro poeta andaluz (1514-1544) al que ha dedicado no hace mucho Jesús Ponce una edición y estudio fundamentales ${ }^{17}$. Como Rufo, Gutierre de Cetina, nacido en 1514, treinta y tres ańos antes que nuestro personaje, era de un linaje de mercaderes de estirpe conversa y es figura típica de la época del Emperador, al igual que Rufo lo es de la de Felipe II. Su familia, moviéndose en un entorno sevillano más pujante que el cordobés, ya había logrado en los primeros años del XVI asimilarse a la oligarquía municipal, cosa que intenta al parecer, sin lograrlo de modo estable, el tintorero Rofos en Córdoba desde la década de 1560.

Juan Rufo, tan ambicioso y dotado como Cetina, tuvo un destino que se cierra con el sabor amargo del desengaño; podría haber intentado una carrera como clérigo o como jurista, y algo así debía de esperar su padre cuando le envió a estudiar a Salamanca, donde el joven llevó una vida disoluta, o al menos disipada, y no logró sacar un título o no lo intentó siquiera. Parece que su temperamento ardiente e inquieto no se avenía con la diligencia y austeridad que se requerían de un letrado de profesión, de un juez o consejero, y menos con la disciplina eclesiástica. La personalidad de Rufo se revela de modo conmovedor en su segundo libro, Las seiscientas apotegmas y otras obras en verso (Toledo, 1596). Entre otras muchas cosas, se deja ver que él marcaba fuertemente la diferencia entre los clérigos y los caballeros (dos tipos que en la corte de Urbino descrita por Castiglione alternaban de modo casi indistinto, y compartían el mismo estilo y la misma ética). Lo ilustra, por ejemplo, este apotegma:

Juraba un obispo muy de ordinario a fe de caballero, y como, aunque lo era mucho, sonaba aquel término de hablar a capa y espada, dijo: “¿Quien debe preciarse de pastor, por qué jura a fe

17 Gutierre de Cetina, Rimas, ed. Jesús Ponce Cárdenas, Madrid, Cátedra, 2014. 
de caballero?" (Apotegma 29) ${ }^{18}$

Con el mismo sentido exactamente, este otro:

Estando en una ventana de las casas del Virrey de Nápoles, tratando con don Bernardino de Mendoza, su hijo, de la sazón que perdía lo bien dicho siendo fuera de propósito, asomó por la calle que va a dar a Chaya un fraile muy reverendo en un caballo que venía dándose con las manos en las cinchas. Visto lo cual, dijo: "Un fraile a caballo parece dicho fuera de propósito" (Apotegma 223) ${ }^{19}$.

Y es que el período histórico que coincide con la madurez de Rufo (desde 1565 hasta la década de 1580) está marcado, como ninguno antes o después, por la huella del concilio de Trento, o dicho de otro modo, por la Reforma católica, que impone normas de gravedad y disciplina en los letrados y clérigos; normas que, por su misma novedad y porque reaccionan contra unas costumbres relajadas que habían indignado a los alumbrados, a los erasmistas y a otros espíritus inquietos, tienen una gran autoridad y capacidad de intimidación. Por esos ańos se considera preceptivo separar estrictamente el estilo galante y abigarrado del militar y el porte severo de la toga, el hábito o la sotana. Tanto rigor moral no durará mucho, como lo prueban, sin ir más lejos, las oportunistas dignidades de cardenal concedidas, durante los reinados de Felipe III y Felipe IV, al fastuoso duque de Lerma y al muy militar y caballeresco Fernando de Austria. Para Rufo, que se tenía por un pecador necesitado de conversión, a juzgar por el epitafio que escribió "estando a la muerte" (apotegma 429) ${ }^{20}$, las obligaciones del pastor de almas implicaban una verdadera renuncia al mundo, un vivir mortificado y penitente, hasta el punto de

18 Las seiscientas apotegmas, $\mathrm{f}$. $9 \mathrm{r}$.

19 Las seiscientas apotegmas, f. 76v.

20 "Estando a la muerte, le consoló un poeta con decirle que, si Dios se le llevase, le haría un solemne epitafio. Al cual dijo que 'pues a otros muchos los había hecho, quería hacerse uno a sí mismo, siquiera porque en semejante sujeto son voces más vivas las de los muertos' y así, en presencia del mismo, hizo este que se sigue: Aqui yace un pecadorl que al morir, nacer quisiera, I no por vivir como quiera; I mas para vivir mejor" (Las seiscientas apotegmas, f. 114r). 
considerar que solo se poseían riquezas para repartirlas a los necesitados ${ }^{21}$. Él no tenía madera ni vocación para ello, y eligió el partido de ser, en sus seiscientas apotegmas y antes en su conversación, un espejo de cortesanos. La protección de don Juan de Austria fue, según él mismo dice, decisiva, y tal vez de haber vivido más tiempo este príncipe, el escritor hubiera consolidado su fortuna y su reputación.

Fracasó en la intentona, que él mismo confiesa ${ }^{22}$, de sustituir al perdido patrón con el quinto duque de Alba, don Antonio Álvarez de Toledo y Beaumont, nieto del famoso tercer duque don Fernando que había cosechado durante medio siglo éxitos militares y desastres políticos. Alba, según cuenta Rufo, no quiso que le sirviera con unas Guerras de Flandes en octava rima, y el proyectado poema se marchitó en flor y no pasó de unas primeras octavas que figuran entre las "otras obras en verso" ańadidas a la serie de apotegmas: quizás el duque no creía en la posibilidad o el interés de una epopeya cuyo héroe fuese su controvertido abuelo. Desde luego no desdeñó al ingenio cordobés por falta de inclinación por los poetas, puesto que es famosa su relación con Lope de Vega, a quien tuvo a su servicio como secretario durante cinco ańos, entre 1590 u 1595, de lo que queda constancia en la Arcadia, o sea, en un libro de pastores que es, en cierto modo; el polo opuesto, dentro de la literatura para nobles cortesanos, al

21 Véase este dicho donde un obispo poco limosnero, que no sabe que los clérigos son mayordomos de los pobres, y que el cielo solo les da bienes para que los administren en favor de los necesitados, es asimilado a un violador y homicida: "Pasando de camino por cierto lugar, cabeza de obispado, donde el obispo tenía fama y obras de poco limosnero, como llegase al amanecer, y hallase en la plaza una pobre, muerta de puro mal pasar, dijo a dos que pedían limosna para enterrarla: '¿Por qué no pedís al mayordomo de esta difunta que dé para su entierro, ya que la forzó y la mató? Preguntado quién era aquel mayordomo. R. Que el clérigo más rico, que la forzó a no comer y la mató de hambre" (Las seiscientas apotegmas, f. 151v).

22 Apotegma 541: "Como quiera que desdenes y necesidad le habían hecho, mal de su grado) no proseguir algunos buenos intentos de su pluma, y uno de ellos (cuyo principio va inserto en este volumen) se marchitó en flor porque el duque de Alba don Antonio no fue servido de apoyar aquella empresa cuando se la dedicó. Y como el capitán Diego de Escobar le dijese que de qué podía servir el enjerir en su libro aquel principio sino de dentera para los que se habían señalado honradamente en las guerras de Flandes: Sirva de letra de aviso, / para que ninguno dude / del duque el desdén preciso: / quise servirle y no pude, / pudo mandarme y no quiso"(Las seiscientas apotegmas, f. 145r). 
de la épica ${ }^{23}$. Tal vez fuera una cuestión de generación: eran exactos contemporáneos don Juan de Austria y Juan Rufo, nacidos probablemente el mismo año de 1547. Antonio Álvarez de Toledo y Beaumont nació en 1568, de modo que Lope solo le llevaba seis años, y su viveza y carácter fogoso compensaba lo que pudiera tener de más viejo que el duque. Estas amistades desiguales de noble a poeta se fraguaron en los dos casos cuando los interesados eran muy jóvenes, ambiciosos y llenos de vida.

A fin de cuentas, Juan Rufo, sintiéndose dotado del talento necesario para arrostrar la carta de las letras, y de una cultura que bastaba para un ingenio de corte, se inclinó a llevar su carrera literaria por un camino muy diferente al de la lírica petrarquista, dominante a mediados de siglo, que había escogido Cetina. El ennoblecimiento que podía esperar gracias a sus dotes naturales y mediante el cultivo de la poesía no podía proceder, en su caso, de la lírica amorosa. Esta lírica, en los años del Escorial y de Lepanto, y en círculos cortesanos, se consideraba demasiado liviana para conferir reputación a alguien que no la tuviera ya por la sangre o por méritos excepcionales. Al fin y al cabo, de los poetas enamorados autores de romances podía decirse, "que estaban locos, pues se confesaban a gritos", como lo hizo, para escándalo de unos y fascinación de otros, el mismísimo Lope de Vega, llevando a la plaza pública sus amoríos ${ }^{24}$. Estar enamorado y estar en pecado mortal no era cosa muy diferente. Y para hacer buenos versos amorosos, había que estar de verdad enamorado, de lo que se deduce que ser buen poeta lírico era confesarse gran pecador, a menos que uno estuviera enamorado de la propia mujer. Pero esto resultaba más bien ridículo en un cortesano, no siendo la mujer una gran señora, como no era ni podía ser la esposa de Rufo. Así nos parece intuirlo en el apotegma 128, que habla de un personaje cuyo nombre omite, dejando entrever que se trata de un gran señor muy celoso de su alta posición. Este personaje estaba enamorado de su mujer y le escribía versos que, por ser él y su esposa quienes eran, alcanzaban el prodigio de ser a la vez buena poesía y expresión de sentimientos virtuosos:

Cierto personaje (cuyo nombre se calla, porque es digno de mayor elogio que el que permite la intención de este libro) era muy bien

23 Véase Jesús Cañas Murillo, "Lope de Vega, Alba de Tormes y la formación de la comedia", Anuario de Lope de Vega (2000), pp. 75-92.

24 Apotegma 8. Las seiscientas apotegmas, f. 4r. 
casado y tan enamorado galán de su mujer, que no tomaba vez la pluma para poetizar (cosa que entre otras sabía muy bien hacer) que no fuese para celebrar sus grandes partes y lo mucho que la quería. Estando pues en presencia de ella misma, leyéndole un gran volumen de diversas poesías, todas conformes en ser de aquel sujeto, le dijo: "Versos amorosos y buenos, suelen ser engendrados en pecado mortal, mas estos son hijos de bendición" 25 .

Uno de los lugares de La Austríada en donde Rufo bosqueja un canon de poetas para situar entre ellos a su propia musa, se halla al comienzo del canto XXI, cuando se abre la parte más heroica de los hechos de don Juan de Austria, en vísperas de la famosa batalla naval. Hasta entonces, ni aun para los mejor intencionados era posible glorificar la confusa y sanguinaria guerra de las Alpujarras, tan llena de torpezas, rivalidades mezquinas, pillajes anárquicos y masacres insensatas:

Si aquel que a Grecia hizo tan famosa y de Troya cantó en verso sonoro, la guerra con los griegos espantosa, el duro incendio y el funesto lloro; o el otro, cuya mano artificiosa sus amores pintó con el decoro que a la hermosa Laura se debía y al verdadero amor que le tenía;

o el que de Eneas el destierro y males, el ardid, la piedad y el sufrimiento encareció con versos inmortales y más que humana forma de talento; o esotro, que en materias desiguales, igualmente subió el entendimiento, y en un jardín de flores abundoso, nos introdujo a Orlando el Furïoso;

o el cordobés poeta castellano, y intitulado así por excelencia,

25 Las seiscientas apotegmas, f. $172 \mathrm{v}$. 
que compuso en estilo sobrehumano, guïado por divina providencia;

o el celebrado ingenio de Lucano, que escribió la farsalia competencia en son tan dulce que de gente en gente volará su memoria eternamente... ${ }^{26}$

Los emparejamientos entre un antiguo y un moderno, nombrados o aludidos mediante perífrasis, son muy meditados y nada caprichosos: a Juan de Mena, "el cordobés poeta castellano... guïado por divina providencia”, y a Lucano, que escribió de las guerras civiles romanas, debía de asociarlos Rufo como a autores heroicos y graves, sentenciosos y políticos, historiadores tanto como poetas: por tales motivos, y por ser ambos cordobeses, eran sus modelos más cercanos. A Virgilio ("el que de Eneas el destierro y males [...] encareció con versos inmortales") y a Ariosto, florido autor del Orlando furioso, cabía vincularlos porque los aficionados al ferrarés lo igualaban con el sublime poeta romano y porque eran las cimas de una épica noble, abierta a la fábula y a lo maravilloso. Homero, "el que a Grecia hizo tan famosa, y de Troya cantó en verso sonoro", y Petrarca que sus amores "pintó con el decoro" que se debía a su hermosa Laura, aludidos en la primera octava, aun siendo los modelos más alejados de Rufo, aparecen en apertura del canto, y en la cima del Parnaso, como padres de la poesía antigua y de la moderna.

En la cultura literaria imperante en España durante la segunda mitad del XVI, para un laico que quisiera conquistar la honra del escritor, y tuviera facilidad y gusto para el verso, cabía tomar por santo patrón a Homero, como cumbre casi mítica de la épica, o bien unirse a la gran corriente de ese petrarquismo italiano e internacional que había dominado la literatura a mediados del siglo XVI. Pero esto último solo lo podían hacer con cierta seguridad, por entonces, personajes de mayor abolengo y rango que el jurado de Córdoba.

\section{El COMPROMISO ÉPICO Y SUS DIFICULTADES}

Así las cosas, la vía más prometedora desde la perspectiva de Juan Rufo, quizá la única para alguien en sus circunstancias y que creía en su talento

26 La Austríada, XXI, oct. 1-3. 
literario, era la de la épica de guerra: un género que vivía entonces su momento más afortunado en la Europa meridional, al calor de medio siglo de debates italianos, de la difusión muy reciente, con éxito fulgurante, de la Gerusalemme liberata de Tasso (1579-1581) y de la fama que empezaba a distinguir Os Lusíadas de Camóes. No hay duda de que lo espoleó el hecho de servir a don Juan de Austria. Antes de ganar la Batalla Naval por excelencia, y en verdad antes de haber hecho nada, el hijo de Carlos V ya había sido forjado como héroe. Fue predestinado a serlo por una bastardía que lo privaba de derechos incontrovertibles, heredando de su padre, Carlos V, sobre todo la obligación de parecerse a la imagen idealizada que se tenía del emperador, augusto, piadoso e invencible. Una predestinación que fue corroborada por su belleza física, por la oscuridad que rodeó su infancia, porque ningún defecto de inteligencia o carácter impedía que oficiara de héroe, y porque todo su entorno le empujaba a serlo, incluyendo a su hermano Felipe II. El rey recurrió a su hermanastro para misiones desagradables o imposibles: sofocar enconadas rebeliones como la de los súbditos moriscos y flamencos, vencer a la armada otomana o recuperar a la insostenible Túnez. Sobre la predestinación a la heroicidad de Juan de Austria y el modo en que supo estar a su altura, el poema resulta elocuente y revelador. En cambio, no resolvió muy bien la tensión entre su designio épico y el compromiso de verdad histórica. Este compromiso actuó indudablemente como un lastre en su composición. Lo sugieren apotegmas como estos:

El secretario Juan de Soto, trataba en Nápoles (por comisión del señor don Juan) de resumir lo que tocaba a su asiento y darle las relaciones de la guerra de Granada. Y como esto se dilatase, una vez porque llegaba una escuadra de galeras, y otra porque se despachaba un correo: ya por un regocijo, ya por un mortuorio, le dijo: "Enfermos andan mis negocios, que cualquiera mudanza de tiempo les hace mal" 27 .

Leyendo su obra, cuando estaba de mano a Juan Andrea y Juan de Soto, buenos testigos de la batalla Naval, se dificultó entre ellos, si cierto personaje de los que murieron allí, murió de arcabuzazo, o

27 Apotegma 287. Las seiscientas apotegmas, f. $74 \mathrm{v}$. 
no, y díjoles: "Cuando no haya sido de arcabuzazo, ¿qué importa que se le demos de limosna, pues nadie le querrá al precio?”28.

Estas anécdotas tienen la virtud de dejarnos apreciar el carácter de Rufo, su gracia, sal y agudeza, su humorismo, diríamos hoy, que hizo que fuese buscado por personas de toda condición, desde las más modestas a las de rango muy superior al suyo. También ponderan de modo muy gráfico la larga y espinosa labor de reunir y contrastar información, requerida por la escritura de un poema que es también historia. No historia de hechos polvorientos y olvidados sino historia reciente, de la que se sentían partícipes multitud de personas vivas, capaces de quejarse por no haber sido tratadas como era debido, ellas mismas o en cabeza de sus parientes y aliados. Hacer morir de un arcabuzazo a alguien que hubiera muerto de otro modo y que, por ejemplo, hubiera caído en un combate cuerpo a cuerpo, herido por un alfanje, era cosa de la que sus hermanos, hijos y amigos podían resentirse $^{29}$. Y, sin embargo, la exactitud en la relación de la muerte de un personaje de tercera fila es cosa que no incide en la llamada grandeza épica. Que esta muerte se produjera de una manera o de otra no afecta a lo que hace del poema un monumento imperecedero: no aumenta ni disminuye sus valores estéticos de intensidad, de patetismo y de magnificencia, su

28 Apotegma 223. Las seiscientas apotegmas, f. $58 \mathrm{r}$.

29 Porque conoce las trabas que pone la historia reciente al arte propio del poeta, el de urdir la fábula con inteligente imaginación, Torquato Tasso, en los Discorsi dell'arte poética (1575), aconseja a los autores de poemas heroicos que escojan un asunto histórico sí, y ocurrido entre cristianos — para que quienes leen compartan los valores de los héroes y simpaticen con ellos-, pero lo bastante remoto como para que ignoren los detalles y no puedan asegurarse de la falsedad de los que el poeta inventa o modifica en pro de la verosimilitud. Así formula el precepto tassiano Francisco Cascales en las Tablas poéticas, donde no hace casi nada más, como es sabido, que traducir a Tasso y a otros italianos: "Ni se ha de tomar la historia muy antigua; porque como la poesía es imitación de los hechos y costumbres, habiendo vos de pintar y representar los ritos antiguos en la acción que tomáis, de ninguna manera daréis contento [...]. Ni será tan moderna que haya testigos que puedan averiguar la verdad; que como el poeta finge para ornamento de su poesía y el otro sabe que aquella es conocida mentira, aunque sea verisímil, no se persuade a creer lo que él sabe de otra manera" (p. 157). Tomamos ambas citas de la siguiente edición: Francisco Cascales, Tablas poéticas, ed. Benito Brancaforte, Madrid, Espasa Calpe, 1975. 
enargeia o capacidad de evocación, el vigor de su pensamiento, el sentido claro que de él se desprende. Y, sin embargo, tales detalles contaban, y eran incluso capitales, para quien abriese el libro buscando su nombre o el de algún pariente o amigo en el gran monumento laboriosamente edificado. La Austríada suponía, pues, un empeño fatigoso y en parte contradictorio: había que ser a la vez un vate, un visionario, un autor inspirado que pide el auxilio de los númenes y un notario puntilloso de datos irrelevantes para el conjunto. La agudeza de Rufo es aquí un chiste por sofisma y equívoco: ¿qué importa que demos gratis (o sea, inmerecidamente, sin que se lo haya ganado el interesado) un arcabuzazo a alguien, puesto que nadie lo querrá al precio, nadie dará nada por él? La discusión de Juan Soto y Juan Andrea Doria se detiene en menudencias que impiden al poeta levantar el vuelo. El ingenio del apotegma consiste en resaltar como mérito del poema su fidelidad escrupulosa a la verdad, a la vez que deja adivinar la noble impaciencia del ardor o "furor" poético que entra en tensión con esta exigencia de relación exacta y minuciosa.

No es, pues, por falta de laboriosidad por lo que Rufo concluyó La Austríada a comienzos de 1580, unos nueve años después del último suceso narrado, cuando había tenido tiempo de leer varios poemas de materia lepantina, como el del napolitano Tommaso Costo, La rotta di Lepanto (Nápoles, 1573) y el del portugués Jerónimo de Corte-Real, $\mathrm{Fe}$ licísima victoria (impreso en 1578, ofrecido en manuscrito a Felipe II dos años antes), además del canto 24 acerca de la batalla que insertó Alonso de Ercilla en la segunda parte de La Araucana (1578).

Este último poeta era sin duda alguna el que más claramente había trazado, en castellano, la vía de una épica de materia histórica reciente. Existe un indudable parecido entre el modo en que se presenta al público el recién bautizado Juan Rufo, jurado de Córdoba, en la edición madrileña de la Austríada de 1584 y la figura de Alonso de Ercilla en los preliminares de la tercera parte de La Araucana (Madrid, Pedro Madrigal, 1590) (Fig. 5). Ambos son representados en busto enmarcado por una orla ovalada, con edad, cabello y barba parecidos, con un cuello muy alto por el que asoma una golilla que roza cabellos y barba, y con elegancia caballeresca, aunque más cortesano Rufo, y Ercilla más soldado, con rica armadura repujada y grabada y ostentando la cruz de Santiago. 


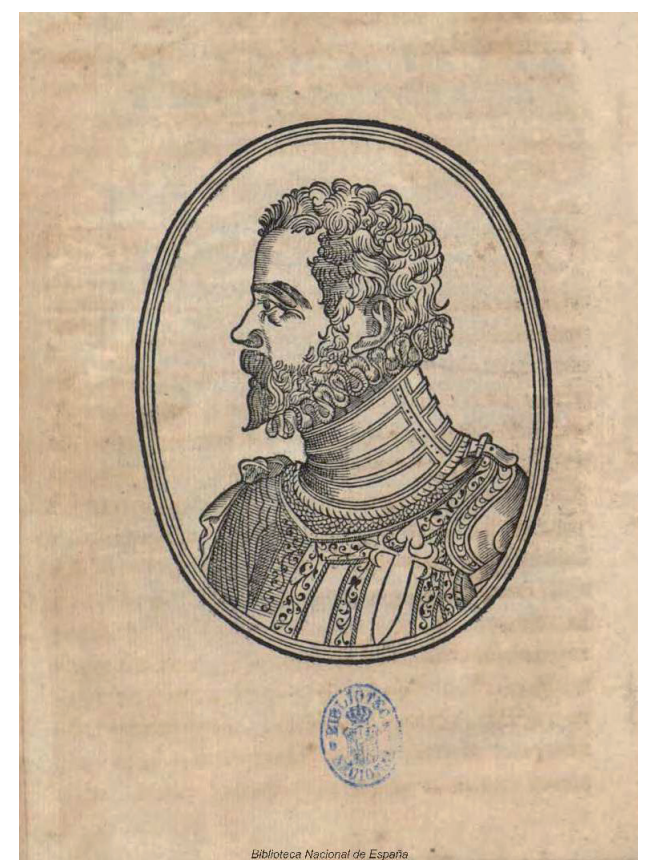

Fig. 5. Retrato de Alonso de Ercilla. Primera, segunda y tercera parte de La Araucana, Madrid, Pedro Madrigal, 1590.

Son similares los retratos, el lugar que ocupan en el libro, la disposición de la portada y la composición del paratexto. Rufo pretendió eclipsar a Ercilla con un poema más decoroso, de asunto más grande y de estilo más solemne. Una serie de tres sonetos, contenida en un manuscrito poético de la Biblioteca Nacional (Fig. 6) ${ }^{30}$, sugiere que eran conscientes de su rivalidad y que se detestaban mutuamente. El primer soneto aplaude con sangriento sarcasmo la publicación de la tercera parte de La Araucana y es atribuido al condestable de Castilla. Siguen en la misma columna dos respuestas del atacado; la segunda, una vitriólica andanada contra Juan Rufo:

$$
\begin{aligned}
& \text { Decid qué es cosa y cosa que ha sacado } \\
& \text { un soneto sin son un chocarrero, } \\
& \text { charlatán, vagamundo y gallofero, }
\end{aligned}
$$

30 Z. Bélaygue, "Deux sonnets inédits d'Ercilla”, Bulletin Hispanique II, 2 (1990), pp. 80-84. 
y, con ser calabaza, muy pesado.

Gran necio de repente y de pensado, hablador importuno, palabrero, que con solo llamarle majadero, apuesto que diréis que es el jurado.

Díganle que un espíritu le avisa no se meta en demandas ni respuestas; en si el palo fue nebro o fue membrillo. Deje estar la Araucana y, a fe mía, guárdese no le llueva el nebro a cuestas y el vacío le mida el colodrillo ${ }^{31}$.

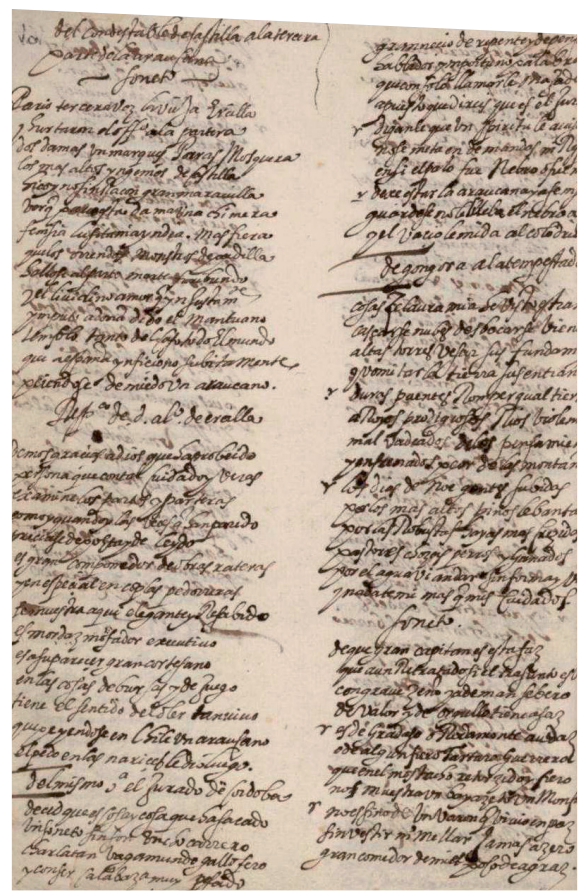

Fig. 6: Un soneto satírico fruto de la rivalidad de Ercilla y Rufo (BNE Mss/3985)

31 BNE MSS/3985, f. 161v. Este manuscrito contiene una colección de poesías copiadas por varias manos que parecen del XVI y de la primera mitad del siglo XVII. Muchas son satíricas y burlescas. Los tres sonetos publicados antes por Bélaygue fueron transcritos por Rafael Ramírez de Arellano, op. cit., pp. 293-294. Agradecemos a Antonio Carreira su ayuda para encontrar este texto. 
El soneto al que este responde no se ha conservado o no ha sido encontrado; no es, desde luego, el soneto satírico contra Ercilla atribuido al condestable ("Parió tercera vez la vieja Ercilla”). Quien escribió estos versos de escarnio pudo ser Ercilla, cosa no probada, o algún amigo suyo indignado por la insolencia del ataque contra el cantor de las guerras de Chile. Fuera quien fuera, no cabe duda de que veía en Rufo al responsable de las burlas o los denuestos contra la Araucana que contenía el soneto perdido: "Deje estar la Araucana”. El “jurado de Córdoba” no poseía las bazas que tenía en la mano Ercilla; su condición de caballero, no puesta en duda por nadie, su crianza como paje del príncipe, sus cargos cortesanos. El autor del soneto juega con esta diferencia, puesto que amenaza a Rufo con apalearlo, como se hace con los plebeyos mal nacidos que se atreven a igualarse con los caballeros, según manda hacer, en la novela de Quevedo, don Diego Coronel con el buscón Pablos, que ha pretendido casarse con una de sus primas.

Además de no poder acreditar la nobleza de su obra por la de su linaje, Rufo tampoco podía, a diferencia de Ercilla, hacerse pasar por un gran soldado ni menos aún convertirse en héroe de su propia gesta. Su trabajo se parece al del historiador, como se desprende de sus propias declaraciones en el prólogo: establecer lo sucedido cotejando testimonios y decantarse por lo más cierto o, a falta de certeza, por lo verosímil. Pero el ingenio cordobés es mucho menos historiador que poeta: más que investigar lo sucedido, urde una rapsodia de materiales tomados de fuentes varias, cronísticas y poéticas, y piensa en términos de composición: composición de cada canto como un todo armónico y vario, y entrelazamiento, en los cantos centrales, de sus dos argumentos: guerra de las Alpujarras entre el rey de España y sus súbditos moriscos; guerra de Chipre entre Venecia y el poder otomano. Son dos guerras locales, en el Mediterráneo occidental y el oriental, de carácter distinto y sin puntos de contacto, que acaban confluyendo en un gran enfrentamiento de dos imperios y en la sonadísima batalla de Lepanto. Ester Cicchetti cita muchas de estas fuentes en su edición de La Austríada, reuniendo materiales muy útiles para analizar el trabajo de reescritura o imitación compuesta.

Es probable que el autor del perdido soneto al que responde el epigrama satírico contra Rufo pusiera en ridículo el bastón de enebro ("nebro") con el que un viejo pariente del jefe indio Caupolicán mata a Pedro de 
Valdivia, gobernador de Chile, como quien desnuca a una res en el matadero; el detalle subrayaba la falta de dignidad épica y de decoro en la representación de la muerte de un héroe, de un conquistador como Valdivia:

Valdivia, como mísero cautivo, responde y pide humilde y obediente que no le de la muerte, y que le jura dejar libre la tierra en paz segura.

Cuentan que estuvo de tomar movido del contrito Valdivia aquel consejo; mas un pariente suyo empedernido, a quien él respetaba por ser viejo, le dice: "Por dar crédito a un rendido quieres perder tal tiempo y aparejo?" Y apuntando a Valdivia en el celebro descarga un gran bastón de duro enebro.

Como el furioso toro, que apremiado con fuerte amarra al palo, está bramando, de la tímida gente rodeado, que con admiración le está mirando; y el diestro carnicero ejercitado, el grave y duro mazo levantando, recio al cogote cóncavo desciende, y muerto estremeciéndose le tiende... ${ }^{32}$

Escritura recia y despiadada la de Ercilla, con efectos plásticos, pero humillantes para el personaje del guerrero espańol y devastadores para su memoria, que en vano buscaríamos en Rufo. Más que por la lógica de la narración y el trazado de los personajes, bastante planos, el poeta cordobés intenta elevar su historia a la majestad épica con medios retóricos: arengas, cronografías, descripciones de combates (un arte para el cual no posee, en nuestra opinión, las dotes de Ercilla o de Ariosto), comparaciones y "sentencias", o sea, comentarios morales y políticos en fórmu-

32 Alonso de Ercilla, La Araucana, III, vv. 509-520. 
las concisas y memorables, y sobre todo una lengua muy controlada, de acento siempre grave y culto, pero sin figuras demasiado vistosas o difíciles. Es el suyo un arte herreriano, si puede decirse así, muy de su tiempo, muy acorde con el tono solemne y austero de Felipe II o de la emperatriz viuda a la que está dedicado el poema. La apreciación del poema por sus contemporáneos pone de relieve esta dignidad estilística uniforme destinada a conferir a la historia un aspecto decorativo y monumental: en el "Memorial del reino a Su Majestad", escrito de ciertos procuradores en cortes como recomendación de Rufo al rey, se "lee que el estilo es fácil, elocuente, grave y sustancial", y que "la dicha historia, comenzándose a celebrar y hacer inmortal la memoria y nombre del señor don Juan, como lo merecieron sus obras y hazańas, redundará así mismo en no menor beneficio y alabanza de la lengua castellana y ingenios de esta nación”. Se trata, a fin de cuentas, de mejorar la lengua, poniéndola a la altura de las hazañas del héroe, de modo que la gloria esté dudosa entre el poeta y el príncipe, según el audaz concepto que vertebra el soneto encomiástico de Luis de Góngora incluido en los preliminares:

$$
\begin{aligned}
& \text { Cantastes, Rufo, tan heroicamente } \\
& \text { de aquel César novel la heroica historia, } \\
& \text { que está dudosa entre los dos la gloria, } \\
& \text { y a cuál se deba dar ninguno siente; } \\
& \text { y así la fama, que hoy de gente en gente } \\
& \text { quiere que de los dos la igual memoria } \\
& \text { del tiempo y del olvido haya victoria, } \\
& \text { ciña de lauro a cada cual la frente... }
\end{aligned}
$$

Más preciso es Lupercio Leonardo de Argensola, en un elogio compuesto de cuatro octavas que también figura en los preliminares. Rufo es el heredero de dos cordobeses; de Séneca, por las sentencias; de Lucano por el estilo:

la doctrina de Séneca más grave, camino tan sabido de los buenos, y resplandor de Córdoba y España, en sus doctas sentencias le acompańa.

$\mathrm{Ni}$ el estilo le falta verdadero 


\section{del que cantó tus guerras, bella Italia, y aquella sujeción y yugo fiero nacidos en los campos de Tesalia...}

El trabajo de Ester Cicchetti, editora de la Austríada, es especialmente valioso por el análisis cuidadoso que, en su calidad de lingüista de formación y vocación, dedica a la lengua y al estilo: pone de manifiesto la elegante disposición de las octavas, la precisión y variedad del vocabulario, y la abundancia de cultismos. Puede deplorarse el manejo de este concepto de cultismo, que no tiene una definición rigurosa, y el hecho de que, a estas alturas del siglo XXI y con los medios digitales a nuestro alcance en lexicografía, tengamos que contentarnos con las listas de cultismos gongorinos establecidas por Dámaso Alonso. El estudio basta, con todo, para acreditar las afirmaciones de los contemporáneos del poeta y la impresión que produce aun hoy. Rufo tenía un gran sentido de la lengua y fue capaz de poner en circulación muchas palabras y expresiones nuevas o poco usadas sin dar la impresión de forzar el idioma ni obligar al lector a esfuerzos inhabituales de comprensión; sin rebajar tampoco el tono de gravedad que caracteriza al conjunto.

\section{Del cantor de Juan de Austria al "ingenioso Rufo": desengaño Y FORTUNA PÓSTUMA}

Pese a que los elogios a su lengua y estilo no fueran infundados, lo cierto es que La Austríada no logró una fama a la altura de sus ambiciones, y que, lejos de alcanzar victoria sobre la muerte y el olvido, como le auguraba el joven Góngora, fue olvidada con bastante rapidez; el mismo Rufo se dio cuenta de ello. En vez de continuarla, como lo esperaba, o de emprender otra epopeya similar sobre "las guerras de Flandes", dejó pasar doce ańos hasta publicar, en Toledo, otra obra mucho menos altisonante, pero no menos notable: Las seiscientas apotegmas...y otras obras en verso, un libro testamento, que reúne, en una empresa inaudita, sus propios dichos: "breves y agudas sentencias, dichos y respuestas", como él mismo los define. Hay entre estos dichos buenos chistes, que nunca caen en lo trivial o escatológico, otros de refinada galantería, otros graves y sentenciosos, muchos de reflexión melancólica sobre el propio desam- 
paro, otros de confidencia sobre sus relaciones personales con amigos, mujeres, patronos, y en varias ocasiones con su querido hijo Luis. Dedica sus apotegmas al príncipe Felipe, entonces muchacho de dieciocho años, esperando obtener de él

la [merced] que baste para emplear la vida en loables estudios, ya que por falta de arrimo ha perdido parte de lo mejor de su edad. Y así solo presenta a V. A. como a sacro y excelso templo, las plumas y los cabellos que al tiempo y a la Ocasión arrebató de las alas y la frente, en presencia de personas que viven hoy.

Por un bello concepto por correspondencia y doble alegoría, los apotegmas son plumas arrebatadas de las alas de un Tiempo perdido, y dichos improvisados, surgidos al calor de las circunstancias, cabellos arrebatados en la frente de la Ocasión. Cabellos y plumas sugieren algo leve y menudo, pero también el modo en el que un ingenio inagotable "discurre a la ocasión" y se revela capaz de producir la más larga colección de dichos ingeniosos procedentes de uno solo, para lo cual vale el testimonio "de personas que viven hoy".

Las seiscientas apotegmas, contrariamente a la Floresta española de apotegmas de Melchor de Santa Cruz (Toledo, 1574) ${ }^{33}$, de gran éxito español y europeo, no fueron reimpresas y tuvieron, a juzgar por ello y por la ausencia de menciones entre sus contemporáneos, una fría acogida. Tampoco por medio de este libro, que hoy resulta menos indigesto que La Austríada, consiguió protectores Rufo, lo que determinó sin duda su decisión de volver a llamarse Juan Gutiérrez y ejercer de tintorero, como su padre, en sus últimas décadas de vida, transcurridas, al parecer, en completa oscuridad.

Medio siglo más tarde, sin embargo, su fama reverdeció gracias al escritor más brillante de mediados del XVII, Baltasar Gracián, al ser Rufo de los autores más elogiados y a menudo citados en la Agudeza y arte de ingenio (1648). El jesuita leyó a fondo sus Seiscientas apotegmas y otras obras en verso, aunque lo ignora por completo como poeta épico. En la versión larga del tratado, cita siete veces el romance de los comendadores, dos veces el soneto que comienza "Di, Ana, ¿eres Diana? No es posible", una vez

33 De 1574 a 1669 se publicaron veinticinco ediciones seguras, una traducción francesa, otra italiana y una traducción alemana parcial. Véase Melchor de Santa Cruz, Floresta española, eds. Pilar Cuartero y Maxime Chevalier, Barcelona, Crítica, 1997, p. LVII. 
la "Carta a su hijo siendo muy niño", una vez el "Romance en alabanza de la comedia" y 21 de los "seiscientos" apotegmas ${ }^{34}$. La primera vez que saca a relucir a Rufo lo hace sin nombrarlo y llamándolo "el cordobés agudo", como si no necesitara decir más, pese al equívoco que afecta esta perífrasis, puesto que Góngora también fue cordobés y, para Gracián, un “águila en los conceptos”, el más agudo de los poetas junto con Marcial. El autor de Las seiscientas apotegmas vuelve a aparecer como "el cordobés jurado", "el ingenioso jurado", "el pronto Rufo", "el agudo jurado”, "aquel gran benemérito de la grandeza, Rufo", "el pronto Rufo", "el agudo en verso y prosa Juan Rufo", "el jurado de Córdoba”, "aquel que juró de agudo”, “el fino cordobés Rufo con su donosa prontitud”, el "agudísimo Rufo", de nuevo "el jurado”, "el jurado de Córdoba”, "aquel bien conocido español por sus prontos y sazonados dichos", "el galante y agudo Rufo", "el culto jurado”, "el cuerdo, sobre ingenioso, Rufo". Toda una gavilla, pues, de epítetos encomiásticos que hacen de Rufo un campeón de la agudeza, en su vertiente de prontitud, o sea, de rapidez y oportunidad en los hallazgos ingeniosos. El cargo municipal que detentó el escritor le permite a Gracián jugar con las palabras ("el que juró de agudo") y convertir a un personaje que solo fue jurado por un tiempo limitado, que no tenía vocación alguna de burócrata y sí mucha de aristócrata, en el jurado por excelencia, lo mismo que hace de él el cordobés por antonomasia.

Los apotegmas y poemas citados por Gracián presentan numerosas variantes con respecto a los que aparecen en la prínceps de Las seiscientas apotegmas y otras obras en verso; algunas podrían explicarse porque el aragonés citaba de memoria, sobre todo las prosas y miraba más el sentido que la letra, salvo para los juegos de palabras. Sin embargo, no puede descartarse que el libro que manejó el jesuita fuera un ejemplar, no de la edición prínceps de 1596, sino de la edición toledana de 1613, citada por Nicolás Antonio, de la que no se han hallado ejemplares y que podía diferir de la primera ${ }^{35}$. De existir esa edición, Rufo no habría renunciado

34 Rufo es traído a colación para ilustrar muchas especies de agudeza, en los discursos V, VI, IX, X, XI, XII, XVI, XVII, XX, XXV, XXVI, XXVII, XXVIII, XXIX, XXXI, XXXII, XXXIV, XXXIX, XLII, XLVIII.

35 Vale la pena citar por entero, por muy significativo para nuestro propósito, el texto de Nicolás Antonio, Bibliotheca Hispana Nova, Madrid, Joaquín de Ibarra, 1783. I, p. 772: "Ioannes Rufo Gutierrez, Cordubensis, hujusque nobilissimae urbis, ut 
a las letras tan completamente como se pensaba.

Los biógrafos y editores han mencionado, al hablar de la fortuna de nuestro autor, este aprecio extraordinario que de él hace Gracián. Tal vez por influencia suya, autores de la segunda mitad del XVII y del siglo siguiente tienen en cuenta el segundo libro de Juan Rufo. González de Amezúa señala que Tomás de Llamazares, en sus Apophtegmas en romance (Lyon, 1670), lo cita en el prólogo e incluye varios de sus apotegmas en su antología; dos decenas de ellos son traducidos al portugués en el libro de Pedro José Suppico de Moraes, Colleção politica de apotegmas ou ditos agudos e sentenciosos (Lisboa, 1718). Francisco Asensio, al compilar una Segunda Parte de la Floresta española (Madrid, 1730), incluye 77 dichos del cordobés ${ }^{36}$. No sabemos, en cambio, que se haya comentado la existencia de manuscritos de la segunda mitad del XVII que copian una selección de sus apotegmas, junto a otros textos de tipo sentencioso o

dicunt, juratus, ingenio alacer ac disertus vir, cujus epigrammata breviori carmine octosyllabo, sententiarum aculeis innocenter armata, fere omnium illorum ore non cadunt, qui his non inutilibus nugis delectantur, quoties de similibus jocis et facetiis recurrit sermo. Scripsit pure ac perspicue de victoria navali ad Naupactum a turcis reportata XXIV librorum seu canticorum historiam, cui a Joanne Austriaco, Christianae classis summo praefecto inscripsit: La Austríada. Compluti apud Ioannem Gratianum, 1586, in 8. Necnon \& inscripsit: Las Seiscientas Apotechmas y otras cosas en verso. Toleti 1596. in. 8. 1613. in 4" "Juan Rufo Gutierrez, cordobés, y jurado, como lo llaman, de esa nobilísima ciudad, de ingenio acre y elocuente, cuyos epigramas en metro breve, armados inocentemente por los agudos pensamientos, andan en boca de todos aquellos que se deleitan con estos donaires no carentes de utilidad, cada vez que se presenta la ocasión de discurrir de forma burlona y graciosa. Escribió, con pureza y claridad, acerca de la victoria naval habida sobre los turcos en el golfo de Lepanto, una historia en veinticuatro libros o cantos, a la cual dio título tomado de Juan de Austria, general en jefe de la armada cristiana: La Austríada, Alcalá, Juan Gracián 1586, in 8. Y escribió también Las Seiscientas apotegmas y otras cosas en verso, Toledo, 1596. in 8. 1613. In 4’. El texto parece indicar que, que en la segunda mitad del siglo XVII, los versos breves de Rufo eran muy conocidos, y que la gente los citaba como sentencias y donaires memorables.

36 Se verá información más detallada, facilitada por el editor, en Juan Rufo, Las seiscientas apotegmas y otras obras en verso, ed. Alberto Blecua, Madrid, Espasa-Calpe, 1972, pp. XLIV-XLV. Sin embargo, en su edición no tiene en cuenta las variantes en los textos compilados por estos antólogos, y menos la tradición manuscrita, quizá por considerar que el único texto con autoridad es el que hizo imprimir el propio Rufo en 1596, sin tomar en cuenta la posibilidad de que los textos copiados en el siglo XVII contengan huellas de la segunda edición perdida. 
de análisis político. Dos de ellos se encuentran en la Biblioteca Digital Hispánica: el Mss/183 de la BNE, titulado en el catálogo Tratados varios, contiene una serie de textos breves y fragmentos numerados, reproducidos con excelente letra. El amanuense inicia el manuscrito transcribiendo 208 apotegmas de nuestro autor, encabezando la serie con el título Apotegmas de Juan Rufo, Jurado de Córdoba, año 1596; a partir del folio 22 sigue copiando, con la misma numeración, ejemplos de agudeza citados en la Agudeza y arte de ingenio "de Lorenzo Gracián infanzón"; luego transcribe fragmentos de las Oratorias instituciones latinas, españolas del P. Josef de Olzina (1652); desde el folio 359v, recoge cuentos tomados de los Diálogos de entretenimiento de Lucas Hidalgo; a partir del folio 387v, apotegmas de Erasmo en latín, seguidos por extractos de Exemplorum memorabilium de Andrés de Resende y Nicolas Nivelle. Parece claro que el manuscrito estaba destinado a la educación retórica de un joven, tal vez por orden de su preceptor o de algún profesor. Quien compiló o mandó compilar el códice pudo colocar a Rufo en primera posición en virtud de la eminencia como autor agudo y sentencioso que le daba Gracián en su tratado, un libro que el dueño del manuscrito conocía y admiraba, puesto que recoge o manda recoger todos sus ejemplos ordenados por discursos. El método de aprendizaje conjunto de la elocuencia y de la prudencia que el responsable del códice preconiza implícitamente es del mismo tipo que el que el jesuita recomienda en todos sus libros.

En cuanto al segundo códice, catalogado como "Papeles varios" (Mss/18103), el catálogo lo atribuye a García Sarmiento de Montemayor, conde de Salvatierra (1618-1659), quizá porque procede de su biblioteca o porque contiene dos originales de cartas de la duquesa de Mantua dirigidas al conde (1 y 10 de marzo 1636). Recoge escritos sobre la situación política española e internacional, como la relación del embajador de Venecia Simón Contarini (1605), discursos que comentan la caída de Olivares, cartas, avisos, panfletos acerca de personajes como Richelieu o Cromwell y análisis de sucesos más tardíos hasta 1665. Todo parece indicar que este manuscrito fue preparado para el uso de un noble cortesano de Carlos II interesado por la situación de la monarquía y por el arte político de los grandes estadistas, tal vez el heredero del conde. A continuación de los citados textos, se recogen "Apotegmas escogidos de Juan Rufo, jurado y natural de Córdoba, que imprimió para el rey Felipe III, siendo príncipe" y luego un catálogo de 
libros (Fig. 7). El hecho prueba que Rufo se estimaba entonces autor digno de ser meditado por un cortesano hábil y reflexivo, con talento o vocación para el gobierno o la diplomacia. Lo mismo indica en fechas muy cercanas a estas, la semblanza que hace Nicolás Antonio de nuestro autor.

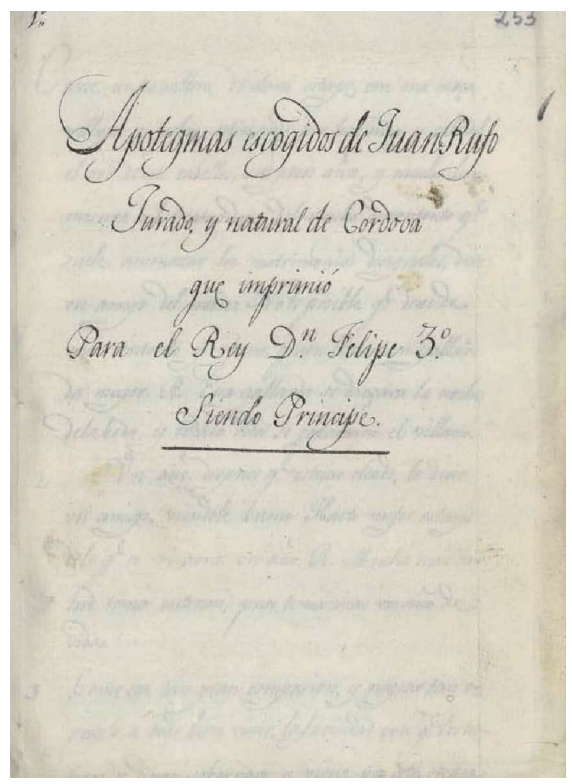

Fig. 7: Rufo en el códice del conde de Salvatierra (BNE Mss/18103)

Otro pequeño dato relacionado con el papel de Gracián en la fortuna póstuma de Rufo no se ha tenido en cuenta hasta hoy. Gracias a Riva Evstifeeva, una joven investigadora que acaba de defender una tesis en Roma acerca de la traducción al ruso del Oráculo Manual en el siglo $\mathrm{XVIII}^{37}$, hemos descubierto que el nombre y algunos textos de Juan Rufo gozaron de una difusión europea. En efecto, como saben los especialistas de Gracián, el Oráculo Manual alcanzó un éxito fulminante a finales del siglo XVII y durante gran parte del XVIII, gracias a Nicolas Amelot de la

37 Riva Evstifeeva, Lessico relativo alle qualità intellettuali in "Pridvornoj Čelovek» (1739), prima traduzione russa dell'Oráculo Manual di B. Gracián, Dottorato di ricerca sin Studi comparati, Università degli Studi di Roma "Tor Vergata", tesis defendida el 16 de abril de 2018. 
Houssaye, un súbdito del Rey Sol, diplomático e historiador, traductor y analista político, quien lo publicó en París en 1684 bajo el título L’homme de $\operatorname{cour}^{38}$ (Fig. 8). Existen como mínimo quince ediciones distintas de este libro anteriores a 1588, y otras muchísimas posteriores, también salidas de prensas situadas lejos de París, y que siguen proliferando hasta bien entrado el XVIII ${ }^{39}$. El efecto de las ediciones del texto francés se prolongó y amplificó con las traducciones alemanas, italianas, latinas, inglesas y en otras varias lenguas, todas derivadas de L'homme de cour y ninguna directamente, hasta bien entrado el siglo XIX, del original español.

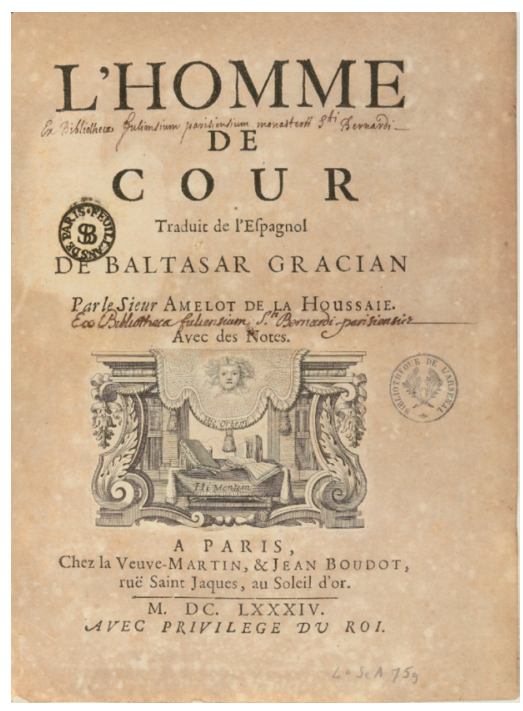

Fig. 8: Frontispicio de la edición princeps de L’homme de cour.

38 Véase Baltasar Gracián, L'Homme de cour, précédé d'un essai de Marc Fumaroli, ed. Sylvia Roubaud, Paris, Gallimard, 2010. La traducción francesa no es la primera, puesto que el libro ya se había publicado en Italia bajo el título de Oracolo Manuale (1670), pero sí con mucho la más importante en términos de recepción. Véase Felice Gambin, "Gracián desde fuera", en Baltasar Gracián: estado de la cuestión y nuevas perspectivas, Zaragoza, Institución "Fernando el Católico", 2001, pp. 165-174.

39 Entre los méritos de la tesis de Riva Evstifeeva, se cuenta el haber completado e intentado hacer exhaustiva la bibliografía de las ediciones de la traducción de Amelot, y también el haberse dado cuenta de que el autor de la traducción la revisó a conciencia en ediciones sucesivas. Va a proseguir esta tarea con el conjunto de las numerosísimas traducciones del Oráculo manual, incluidas las modernas desde el siglo XIX, que ya no derivan de L'homme de cour. 
El hecho obedece a la hegemonía del idioma francés en ese período y al oscurecimiento de la lengua española, pero se debe también a los méritos del trabajo de Amelot. Aunque criticada por los hispanistas y últimamente por su coeditora Sylvia Roubaud, su versión posee cualidades notables: aclara y simplifica a Gracián sin traicionarlo demasiado, haciendo mucho más asimilable lo que su libro tenía de nuevo y de genial. Numera los aforismos y utiliza letra diferente para el inicio de cada uno, que cobra funciones de título, cuando en las ediciones del Oráculo se seguían sin más cesura que un salto de línea (Fig. 9).

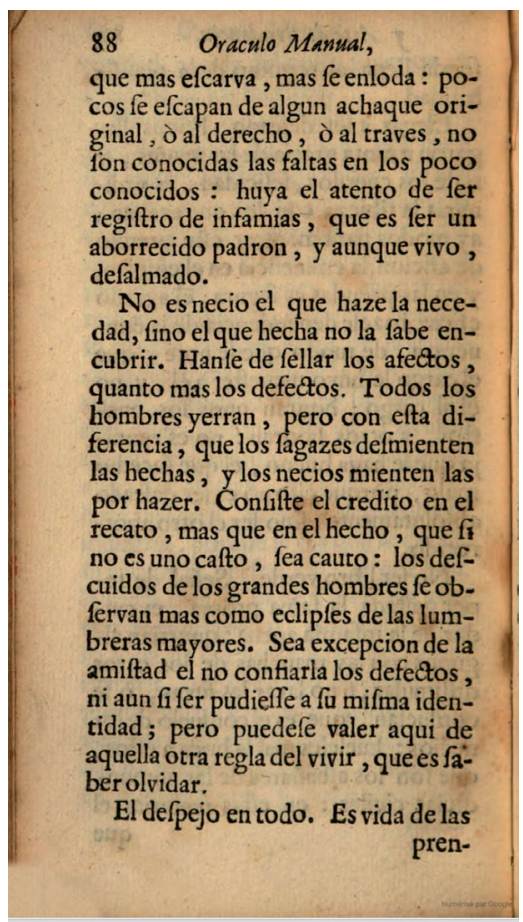

Fig. 9. Una página de Oráculo Manual y arte de prudencia, Amsterdam, en casa de Juan Blaeu, 1659.

El traductor es además un erudito hermeneuta que añade a cada uno de los trescientos aforismos unas glosas de extensión variable, nunca demasiado largas. Cita, con vistas a amplificar e ilustrar la breve máxima del original, fragmentos también traducidos de autores diversos: muchas 
veces el propio Gracián en otras obras suyas, con frecuencia Tácito, ocasionalmente otros autores latinos, como Séneca y Plinio, y muy rara vez autores modernos. Pues bien, entre estos poquísimos modernos citados por el ilustre divulgador de Gracián como fuentes de la prudencia y de la sabiduría del "homme de cour", figura, en grado eminente, nuestro Juan Rufo. L'homme de cour contiene treinta y tres textos suyos (casi siempre apotegmas y en un par de casos, fragmentos de los versos) traducidos al francés, a propósito de los aforismos de Gracián numerados como 14, 19, $22,41,42,52,64,76,90,108,110,112,113,117,118,120,129,135$, 148, 154, 165, 200, 214, 228, 237, 245, 252, 269, 273, 284, 285, 289. Estas traducciones de Rufo por Amelot siguen la fortuna de L'homme de cour y pasan a las traducciones derivadas; por ejemplo, a la de L'huomo de corte, impreso en Roma en 1698, traducido por Francesco Tosques ${ }^{40}$, quien traslada los escolios de Amelot al italiano, ańadiéndoles sus propias glosas, y citas. He aquí un par de ejemplos, referidos a las máximas 154, 269 y 284. La máxima 41, No ser fácil en el querer ni en el querer, N’être facile ni à croire ni à aimer, es ilustrada por un fragmento del romance de Rufo dedicado a su hijo:

\author{
Lo que cierto no estuvieres \\ no te hagas de ello autor; \\ callarlo es mucho mejor \\ mientras dudoso estuvieres; \\ que quien afirma lo incierto, \\ es hombre de poco vaso, \\ y el decir verdad acaso \\ imita el mentir más cierto.
}

(Carta que Juan Rufo escribió a su hijo siendo muy niño, vv. 177-184) ${ }^{41}$

Ne te fais jamais l'auteur de ce que tu ne sauras pas certainement, dit Juan Rufo à son fils; car quiconque affirme une chose incertaine,

40 L'huomo di corte di Baldassar Graziano, tradotto dallo spagnuolo nel francese idioma e comentato dal signor Amelot de la Houssaye, già segretario dell'ambasciata di Francia alla repubblica di Venezia, nuevamente tradotto dal francese nell'italiano e comentato dall'abate Francesco Tosques. Roma, Luca Antonio Chracas, 1698.

41 Las seiscientas apotegmas, f. $233 \mathrm{v}$. 
passera pour homme de peu de capacité; et c'est fort approcher du mensonge que de dire la vérité par hasard. Dans sa lettre en vers (traducción de Amelot, 1688).

Non farti mai autore di quello che non sai di certo, disse Gio. Rufo a suo figlio, perché chi cose non certe afferma, è tenuto per huomo di poca capacità; e'l dir la verità a caso, è avvicinarsi alla bugia. Nella lettera in versi (traducción indirecta de Tosques) ${ }^{42}$.

Para glosar el aforismo 284 del Oráculo, "No sea entremetido y no será desairado", cita Amelot dos apotegmas de Juan Rufo, el 219 y el 6.

Como se requiere modo en todas las cosas, y un personaje, por dar en humilde, diese en menospreciable, le dijo que la estimación honrosa y decente es como la caridad, que comienza en cada uno de sí mismo ${ }^{43}$.

Il en est de l'estime raisonnable de soi-même, dit Juan Rufo, apophtegme 222, comme de la charité bien ordonnée, qui commence toujours par soi-même.

Sia la ragionevole stima di te stesso, dice Giovanni Rufo nell'Apoft. 222, come la ben ordinata carità, la quale dee sempre cominciar da se stesso (traducción Tosques) ${ }^{44}$.

Dijo a un galán ansioso y desvelado por cierto martelo que no tenía discurso entero el que no moderaba su afición con un descuento infalible de pensar que aquello mismo que pretende no es lo que se le representa. Preguntado por qué, dijo "que el objeto de la vista es mayor de cerca, y el del deseo, mayor cuanto más lejos" 45 .

L'objet de la vue, dit le même, est plus grand de près, mais celui du désir est plus grand de loin. Apoftegme 6 (traducción de Amelot, 1684).

42 L'huomo di corte, p. 15.

43 Las seiscientas apotegmas, f. $57 \mathrm{v}$.

44 L'huomo di corte, p. 281.

45 Las seiscientas apotegmas, f. $3 \mathrm{v}$. 
L'oggetto della vista, dice il medesimo, è maggiore da presso, ma quello del desiderio è maggiore da lungi (traducción Tosques) ${ }^{46}$.

Las citas de Rufo pasan tanto a la traducción italiana de Tosques, L'uomo di corte, como a la rusa de Sergej Volchkov (Pridvornoj Čelovek, 1739). No hemos podido comprobarlo en otros casos, pero puede que suceda lo mismo en algunas de las traducciones al inglés, al alemán, al polaco, etc. Nos limitaremos a un par de observaciones sobre el fenómeno.

En primer lugar, Amelot toma más en serio a Juan Rufo de lo que lo hace Gracián. Cita siempre exactamente su nombre, dando el número del apotegma, y traduciendo con gran fidelidad, no parafraseando ni resumiendo. Es interesante ver lo que escoge, que a su vez es vertido a otras lenguas, creando una tradición.

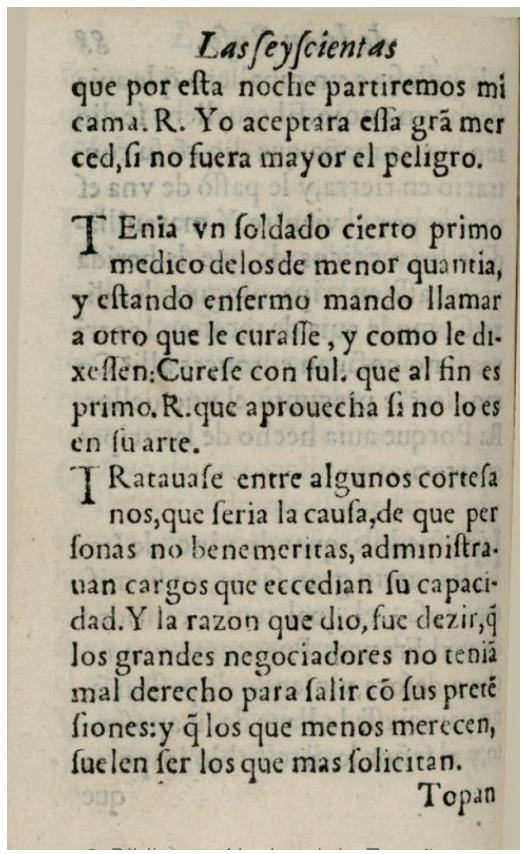

Fig. 10. Una página de Las seiscientas apotegmas y otras obras en verso, Toledo, 1596.

46 L'huomo di corte, p. 281. 
En segundo lugar, interesan estas citas porque delatan el paralelismo entre el tratamiento que impone Amelot a Gracián y el que brinda a Rufo, y hacen ver, de camino, el parecido formal entre Las seiscientas apotegmas y el Oráculo. Ambos son libros "manuales”, de muy pequeño formato, y presentan una colección de textos breves en prosa pertenecientes a un género de estirpe clásica: el aforismo o adagio glosado y el apotegma. Resalta que las piezas de la colección no tengan ninguna marca que permita ordenarlas, ni siquiera un número que las identifique (Fig. 9 y Fig.10). Las "seiscientas apotegmas" son en realidad 707 y el mismo Rufo, que se dio cuenta que había sobrepasado el número anunciado, no sabía exactamente en cuánto. Tanto los aforismos como los apotegmas forman una silva en sentido etimológico, un bosque frondoso en estado salvaje: se presentan en desorden siguiendo leyes complicadas que simulan el azar, buscando la variedad ante todo. Quien maneje uno u otro libro debe encontrar en él su propio itinerario, de modo que la obra presenta un cariz singular e irrepetible para cada lector e incluso para cada consulta. Son lecturas a la ocasión, lecturas ingeniosas, las que estos libros piden. Pues bien, Amelot regulariza del mismo modo en ambos casos, numerando los apotegmas de Rufo, como numera los aforismos de Gracián. La numeración de Alberto Blecua coincide en los números más bajos con la del traductor francés; en los más altos, se observa una discrepancia creciente, como si Amelot contara varios aforismos donde Blecua ve solo uno.

Por lo demás, como ha descubierto Riva Evstifeeva, Amelot no se contentó con reimprimir su versión de Gracián (de la que hubo también numerosas ediciones contrahechas), sino que la revisó cuidadosamente, al menos cinco veces, entre 1684 y 1688. En la prínceps, los apotegmas de Rufo son menos numerosos, y solo aparecen en la segunda mitad del libro; en la edición de 1688 surgen con bastante regularidad a lo largo de toda la serie de aforismos. Lo cual sugiere que, mientras estaba traduciendo el Oráculo, Amelot tuvo la curiosidad de leer Las seiscientas apotegmas, con toda probabilidad porque lo había visto citado y recomendado por Gracián.

Nuestra tercera y última observación es que el Rufo de Amelot no se parece nada al de Gracián. El Rufo de la treintena de citas de Gracián es pocas veces sentencioso y moral: casi siempre es juguetón y galante, autor más donoso que docto, y más notable por sus gracias que por su sensatez y lucidez. Aunque también le merece el epíteto de "cuerdo", "el 
“cordobés jurado" se distingue para Gracián principalmente por su don extraordinario para los apodos, las semejanzas agudas, las paronomasias y los anagramas. En cambio, el Rufo de Amelot se parece, más que al Rufo admirado por Gracián, al propio Gracián. Las citas de Amelot solo en una ocasión coinciden con las del jesuita. Lo que halla el francés en Juan Rufo es un arte de prudencia en miniatura, un condensado del Oráculo Manual donde algunas de las ideas más singulares de Gracián se encuentran ya en estado germinal. Por ejemplo la idea de que hay que desconfiar de los que vienen a valerse de nosotros cuando nos necesitan, porque nos ponen en peligro y gastan nuestras fuerzas ${ }^{47}$; la de que la posesión de un secreto es cosa peliaguda que debe evitarse o disimularse ${ }^{48}$; la de que más vale no entrar "con sobrada expectación" ${ }^{49}$, o sea, que es mejor no ser precedido por

47 Amelot trae a colación el apotegma 599 de Rufo: "Es habla del vulgo que los duendes solían dar noticia de algunos tesoros y que los que callaban los hallaban ciertos; y los que no, vueltos carbón. Y como se tratase del origen que esta fábula había tenido, dijo que la privanza de los Reyes era semejante a esto y que aquél la gozará que menos demostraciones hiciere de privado. Y que cualquier secreto que se fía de tercero es también tesoro de duendes; porque si se calla como se debe, es un rico tesoro; y si se descubre, se convierte en carbón, y a veces encendido". Con ello pretende ilustrar el aforismo 237 de Gracián: "Nunca partir secretos con mayores. Pensará partir peras y partirá piedras. Perecieron muchos de confidentes [...] El que comunicó sus secretos a otro hízose esclavo de él y en soberanos es violencia que no puede durar. Desean volver a redimir la libertad perdida y para esto atropellarán con todo, hasta con la razón. Los secretos, pues, ni oírlos ni decirlos". El pensamiento de ambos no es el mismo pero gira en torno a observaciones parecidas.

48 Nos referimos al apotegma 37: "Mirando un ciruelo enjerto, como tuviese en las ramas que lo estaban mucho más gruesas y sabrosas ciruelas que en algunos propios suyos, dijo que era ejemplo de lo que se debe a los que entran por nuestras puertas para valerse de nosotros". Amelot lo traduce (L'homme de cour, p. 525) para ilustrar el aforismo 285 del Oráculo Manual, que ha escandalizado a muchos: "No PereCer DE DESDicha AJENA. Conozca al que está en el lodo y note que le reclamará para hacer consuelo del recíproco mal. Buscan quien les ayude a llevar la desdicha y los que en la prosperidad le daban espaldas, ahora la mano. Es menester gran tiento con los que se ahogan para acudir al remedio sin peligro".

49 Amelot cita (L'homme de cour, p. 308) el apotegma 31 de Rufo: "El deseo del hombre dijo que 'siempre es mentira, porque aunque se cumpla a medida de su esperanza, nunca llega al justo de lo que pensó”, para ilustrar el aforismo 19 del Oráculo Manual: "No entrar con sobrada expectación. Ordinario desaire de todo lo muy celebrado antes, no llegar después al exceso de lo concebido. Nunca lo verda- 
una excesiva fama de excelencia; y unas cuantas más que deformaríamos tratándolas de modo apresurado.

Lo que permite concluir, provisionalmente, que Amelot nos ayuda a percibir el carácter poliédrico, y menos frívolo de lo que parece, de la segunda obra de Rufo, y entender que en ella depositó, aunque de manera muy personal, otra forma de literatura heroica de estirpe humanística.

Renunciando a la épica, a la literatura de los combates y hazañas, Juan Rufo recurrió a un segundo género de abolengo a la vez cortesano y docto: el de los dichos lacónicos y sublimes, las palabras doradas de hombres ilustres. Estos géneros no carecen de puntos de contacto, pese a parecer diametralmente opuestos: las sentencias y dichos pueden estar aislados como en la colección de apotegmas, o engastados como fragmentos sentenciosos en la narración épica. Así ocurre en las obras de Virgilio y Lucano, los grandes modelos del Rufo épico. El autor de la Farsalia, especialmente, es una verdadera mina de frases rotundas y densas de aspecto paradójico y con valor moral o filosófico ${ }^{50}$. Al igual que la originalidad de Ercilla consiste en transformar al autor en protagonista de su propia epopeya, la de Rufo se cifra en ser el autor de los dichos que recoge, siendo los dichos de uno solo privilegio hasta entonces de los grandes filósofos y los famosos soberanos, un Marco Aurelio, un Alfonso el Magnánimo o un Felipe II. Fue así como logró, después de un precario éxito como poeta épico, una fama póstuma no mucho mas duradera, pero notable, como fénix de la agudeza y maestro de la prudencia.

dero pudo alcanzar a lo imaginado, porque el fingirse las perfecciones es fácil y muy dificultoso el conseguirlas. Cásase la imaginación con el deseo y concibe siempre mucho más de lo que las cosas son. Por grandes que sean las excelencias, no bastan para satisfacer el concepto y como le hallan engańado con la exorbitante expectación más presto le desengañan que le admiran. La esperanza es gran falsificadora de la verdad; corríjala la cordura, procurando que sea superior la fruición al deseo....". Subrayamos la parte del aforismo de Gracián donde Amelot vio, tal vez con razón, un eco del apotegma de Rufo. Véase Baltasar Gracián, L'Homme de cour, pp. 308309. Como ha comprobado Riva Evstifeeva, esta cita de Rufo fue introducida por Amelot, en la edición de 1688 y no figura en la primera, de 1684.

50 Véase el capítulo "Autarchic Limbs: sententiae in Lucan” en Martin T. Dinter, Anatomizing Civil War. Studies in Lucan's Epic Technique, Ann Arbor, University of Michigan Press, 2012. 